\title{
The Application of Hollow Carbon Nanofibers Prepared by Electrospinning to Carbon Dioxide Capture
}

\author{
Yu-Chun Chiang ${ }^{1,2, *}$, Wei-Ting Chin ${ }^{1}$ and Chih-Cheng Huang ${ }^{1}$ \\ 1 Department of Mechanical Engineering, Yuan Ze University, Taoyuan 320, Taiwan; \\ s1060806@mail.yzu.edu.tw (W.-T.C.); s1060807@mail.yzu.edu.tw (C.-C.H.) \\ 2 Fuel Cell Center, Yuan Ze University, Taoyuan 320, Taiwan \\ * Correspondence: ycchiang@saturn.yzu.edu.tw; Tel.: +886-3-4638800 (ext. 2476)
}

Citation: Chiang, Y.-C.; Chin, W.-T.; Huang, C.-C. The Application of Hollow Carbon Nanofibers Prepared by Electrospinning to Carbon Dioxide Capture. Polymers 2021, 13, 3275. https://doi.org/10.3390/ polym 13193275

Academic Editor: Bon-Cheol Ku

Received: 31 August 2021

Accepted: 23 September 2021

Published: 25 September 2021

Publisher's Note: MDPI stays neutral with regard to jurisdictional claims in published maps and institutional affiliations.

Copyright: (c) 2021 by the authors. Licensee MDPI, Basel, Switzerland. This article is an open access article distributed under the terms and conditions of the Creative Commons Attribution (CC BY) license (https:// creativecommons.org/licenses/by/ $4.0 /)$.

\begin{abstract}
Coaxial electrospinning has been considered a straightforward and convenient method for producing hollow nanofibers. Therefore, the objective of this study was to develop hollow activated carbon nanofibers (HACNFs) for $\mathrm{CO}_{2}$ capture in order to reduce emissions of $\mathrm{CO}_{2}$ to the atmosphere and mitigate global warming. Results showed that the sacrificing core could be decomposed at carbonization temperatures above $900{ }^{\circ} \mathrm{C}$, allowing the formation of hollow nanofibers. The average outer diameters of HACNFs ranged from 550 to $750 \mathrm{~nm}$, with a shell thickness of $75 \mathrm{~nm}$. During the carbonization stage, the denitrogenation reactions were significant, while in the $\mathrm{CO}_{2}$ activation process, the release of carbon oxides became prominent. Therefore, the $\mathrm{CO}_{2}$ activation could increase the percentages of $\mathrm{N}=\mathrm{C}$ and quaternary $\mathrm{N}$ groups. The major nitrogen functionalities on most samples were $\mathrm{O}=\mathrm{C}-\mathrm{NH}$ and quaternary $\mathrm{N}$. However, $=\mathrm{C}$ and quaternary $\mathrm{N}$ groups were found to be crucial in determining the $\mathrm{CO}_{2}$ adsorption performance. $\mathrm{CO}_{2}$ adsorption on HACNFs occurred due to physical adsorption and was an exothermic reaction. The optimal $\mathrm{CO}_{2}$ adsorption performance was observed for HACNFs carbonized at $900{ }^{\circ} \mathrm{C}$, where $3.03 \mathrm{mmol} / \mathrm{g}(1 \mathrm{~atm})$ and $0.99 \mathrm{mmol} / \mathrm{g}$ $(0.15 \mathrm{~atm})$ were measured at $25^{\circ} \mathrm{C}$. The degradation of $\mathrm{CO}_{2}$ uptakes after 10 adsorption-desorption cyclic runs could be maintained within $8.9 \%$.
\end{abstract}

Keywords: electrospinning; hollow carbon nanofibers; carbon dioxide; adsorption

\section{Introduction}

Anthropogenic carbon dioxide $\left(\mathrm{CO}_{2}\right)$ emissions to the atmosphere have resulted in several global environmental impacts, such as global climate change and global warming. Many countries have announced pledges to achieve net-zero emissions over the coming decades to bring global energy-related $\mathrm{CO}_{2}$ emissions to net zero by 2050. Currently, there is high interest in studies of $\mathrm{CO}_{2}$ capture by adsorption on porous carbonaceous or non-carbonaceous materials [1-3]. However, the development of commercially available porous adsorbents for $\mathrm{CO}_{2}$ capture is still in progress. The volume of pores less than $0.7 \mathrm{~nm}$ in size and the presence of surface nitrogen groups have been regarded as the most important factors determining good $\mathrm{CO}_{2}$ adsorbents [4-8]. Several porous materials have been intensively investigated as potential candidates for $\mathrm{CO}_{2}$ capture, such as activated carbons, activated carbon fibers, carbon nanofibers, zeolites, metal organic frameworks, zeolitic imidazolate frameworks, silica, and carbon nanotubes. Among these porous materials, carbon fibers have attracted much attention due to their unique properties, particularly when they are reduced to the nanoscale [9-11]. Several process techniques have been applied to synthesize polymer nanofibers, such as drawing [12,13], template synthesis [14,15], phase separation [16], self-assembly [17,18], and electrospinning [19,20]. Compared with other methods, electrospinning is acknowledged as a highly versatile, relatively simple, inexpensive, and efficient method for processing polymers into continuous fibers with diameters ranging from nanometers to submicrons $[9,21]$ or mats structures $[22,23]$. 
A basic electrospinning setup comprises a high-voltage power supply, a syringe container, a needle nozzle, and a counter electrode collector [24]. Polymer solutions, especially thermoplastic polymers, are often used as spinning materials. Electrospinning processes involve a complex interplay of surfaces, shapes, rheology, and electrical charge [21,25-27]. The diameter of electrospun nanofibers is highly influenced by the concentration of the polymer, the solution viscosity, and the molecular conformation [26,28]. The electrospinning of polymer solutions only forms polymer droplets in the dilute concentration range because of an insufficient chain overlap. As the concentration is increased, beaded fibers and further uniform fibers can be observed sequentially [29]. Above a minimum concentration, a fibrous structure is stabilized, while the fiber diameter increases with the molecular weight and concentration [28]. For the polymers with higher molecular weights, uniform fibers can be formed at a lower polymer concentration compared with those with lower molecular weights [30]. Therefore, the stabilization of fibrous structures is subject to intermolecular entanglements [31].

When a spinneret (fiber generator) containing two or more channels is employed for feeding different polymer solutions, several types of nanofibers with a special crosssectional configuration, such as core/shell [32], hollow [27], side by side [33], or crimped structure [33], can be produced, depending on the spinneret structure. In addition, blending a sacrificial polymer into another polymer solution can lead to the formation of a porous structure [34]. Coaxial electrospinning is a widely used method for obtaining hollow nanofibers, in which the single spinneret is replaced by a coaxial spinneret. Using this configuration, co-electrospinning immiscible and miscible pairs of polymer solutions forms nanofibers with core/shell structures [35]. Subsequently, the core material can be removed by thermal decomposition [35,36] or extraction with mineral oil or a solvent [37]. It has been suggested that the core-polymer capillary must protrude $\sim 1 \mathrm{~mm}$ below the end of the shell capillary to produce a good Taylor cone at the end of the nozzle $[35,38]$. Good morphologies of polyacrylonitrile (PAN)/poly (methyl methacrylate) (PMMA) nanofibers were obtained from coaxial nozzle electrospinning at $15 \mathrm{kV}$. If the applied electrical voltage was greater than $20 \mathrm{kV}$, the extraction rate of the polymer solution was too fast to evaporate the solvent. Therefore, wet nanofibers were molten together as a bundle of fibers. For an applied voltage of $10 \mathrm{kV}$, the injection was retarded for a period until the electrostatic force was strong enough to inject the solution jet, and some of the nanofibers were molten together to form a bundle morphology [38].

Due to their high specific surface areas, high surface area to volume ratios, easy functionalization, superior mechanical properties, outstanding flexibility, controllability in fiber diameter, surface morphology, fibrous structure [24], etc., hollow carbon nanofibers have significant potential for application in domains as diverse as drug delivery [39] and as a scaffold for tissue engineering [40], in the capacitive deionization process for water treatment [41], and in energy [42-46].

Electrospinning techniques have become a straightforward and convenient method for producing continuous and porous carbon nanofibers [20]. However, they have very few applications in gas adsorption. Therefore, the objective of this study was to prepare hollow activated carbon nanofibers (HACNFs) in which polyacrylonitrile (PAN) was used as the shell polymer and poly (methyl methacrylate) (PMMA) was selected as the sacrificing core. Thermal treatments have been widely adopted for improving the properties of carbon nanofibers [47]. By means of coaxial electrospinning followed by stabilization, carbonization, and activation, HACNFs were formed. Several properties of the HACNFs were characterized, and the $\mathrm{CO}_{2}$ adsorption on the HACNFs was discussed.

\section{Materials and Methods}

\subsection{Fabrication of Hollow Electrospun Nanofibers}

In this study, hollow carbon nanofibers were synthesized using a coaxial electrospinning process in which polyacrylonitrile (PAN, $\mathrm{Mw}=150 \mathrm{kDa}$, Sigma-Aldrich, Burlington, MA, USA) was selected as the shell polymer and poly (methyl methacrylate) (PMMA, 
$\mathrm{Mw}=120 \mathrm{kDa}$, Sigma-Aldrich) was chosen as the sacrificing core. Firstly, PAN and PMMA were dissolved in N, N-dimethylacetamide (DMAc, Sigma-Aldrich, Burlington, MA, USA) by magnetic stirring at $60{ }^{\circ} \mathrm{C}$ for $24 \mathrm{~h}$ to form homogeneous polymer solutions in concentrations of $10 \mathrm{wt} \%$ and $30 \mathrm{wt} \%$, respectively. The core-shell fibers were fabricated using a coaxial spinneret system in an electrospinning unit (FES-COE, Falco Tech Enterprise Co., Ltd., New Taipei City, Taiwan). The outer needle (18 gauge) had an inner diameter of $0.96 \mathrm{~mm}$ and the inner needle (21 gauge) had inner and outer diameters of 0.52 and $0.82 \mathrm{~mm}$, respectively. The electrospinning was conducted under a work voltage of $15 \mathrm{kV}$ onto a metal drum collector $(\varnothing 10 \mathrm{~cm})$ covered with aluminum foil and rotated at $300 \mathrm{rpm}$, and a work distance (a tip to collector distance) of $15 \mathrm{~cm}$ was used. The feed rates of the shell and core solutions were 1.0 and $0.5 \mathrm{~mL} / \mathrm{h} \mathrm{[36],} \mathrm{respectively,} \mathrm{and}$ the process was propelled by two syringe pumps (NE-1000, New Era Pump Systems, Inc., Farmingdale, NY, USA).

The collected core-shell nanofibers were stabilized in a furnace with an air atmosphere from room temperature to $280{ }^{\circ} \mathrm{C}$ with a heating rate of $1^{\circ} \mathrm{C} / \mathrm{min}$; then, the temperature was held at $280^{\circ} \mathrm{C}$ for $12 \mathrm{~h}$ to finish the cyclization and dehydrogenation reactions and convert PAN from a thermoplastic to non-plastic compound $[48,49]$. This is a significant step in fabricating ACNFs due to the formation of a conjugated ladder structure [50]. The stabilized nanofibers were cooled down to room temperature and then carbonized at 900,1000 , or $1100{ }^{\circ} \mathrm{C}$ with a heating rate of $5{ }^{\circ} \mathrm{C} / \mathrm{min}$ and maintained for $1 \mathrm{~h}$ under flowing nitrogen with a flow of $100 \mathrm{sccm}$ in a tubular furnace [43]. After carbonization, the activation of the samples was accomplished by raising the temperature to $850{ }^{\circ} \mathrm{C}$ at a rate of $10{ }^{\circ} \mathrm{C} / \mathrm{min}$ in a nitrogen atmosphere. The activation agent was a pure $\mathrm{CO}_{2}$ gas, which was switched in when a temperature of $850{ }^{\circ} \mathrm{C}$ was reached in a tubular furnace and maintained for $1 \mathrm{~h}$ with a flow rate of $100 \mathrm{sccm}$. The samples carbonized at 900, 1000, or $1100{ }^{\circ} \mathrm{C}$ were labeled as C900, C1000, or C1100, respectively. After the carbonized samples were further activated, they were denoted as A900-850, A1000-850, or A1100-850.

\subsection{Characterizations}

Field emission scanning electron microscopy (FESEM) was utilized to observe the morphology of the samples using a scanning electron microscope (S-4800, Hitachi, Krefeld, Germany). The elemental compositions in the samples were analyzed using elemental analysis (EA), where the weight percent (wt.\%) of the $\mathrm{C}, \mathrm{H}$, and $\mathrm{N}$ elements was measured by an elemental analyzer (Elementar vario EL cube, Langenselbold, Germany). Fourier transform infrared (FTIR) spectroscopy is a technique used to obtain an infrared spectrum of absorption or emission of a solid. However, FTIR could not give much information about chemical structures for carbonaceous materials [51] due to the strong absorption of infrared light by the carbon. Therefore, FTIR with attenuated total reflectance (ATR) mode was used to obtain the FTIR spectra of the samples. The FTIR spectra were acquired using a FTIR spectrometer (Perkin Elmer, Spectrum 100, Waltham, MA, USA) in a range of wavenumbers from 4000 to $650 \mathrm{~cm}^{-1}$ at a resolution of $4 \mathrm{~cm}^{-1}$. The number and type of functional groups present on the surface of the samples were analyzed using X-ray photoelectron spectroscopy (XPS), in which information on the elements within a few nanometers of the sample surface could be obtained. The XPS spectra were collected using a spectrophotometer (PHI 5000 VersaProbe II, ULVAC-PHI, Kanagawa, Japan), in which a scanning X-ray monochromator (Al Anode, hv $=1401 \mathrm{eV}$ ) was used. For calibration purposes, the $\mathrm{C} 1 \mathrm{~s}$ electron binding energy (BE) that corresponds to graphitic carbon was set at $285 \mathrm{eV}$. A nonlinear least squares curve-fitting program (XPSPEAK software, version 4.1, The Chinese University of Hong Kong, Hong Kong, China) was employed in the deconvolution of the XPS spectra. $\mathrm{N}_{2}$ adsorption-desorption isotherms measured at $-196{ }^{\circ} \mathrm{C}$ using an ASAP 2020 accelerated surface area and porosimetry system (Micromeritics, Norcross, GA, USA) were investigated in order to find the surface structures of the samples. All samples were degassed at $350{ }^{\circ} \mathrm{C}$ for $24 \mathrm{~h}$ to eliminate the interference of the moisture and trace gases prior to the adsorption measurements. The specific surface areas (SSAs) 
of the samples were determined at relative pressures from 0.05 to 0.3 using the BrunauerEmmett-Teller (BET) method. The micropore $(<2.0 \mathrm{~nm})$ surface area $\left(\mathrm{S}_{\mathrm{mi}}\right)$ was derived using the $t$-plot method. The single point total pore volume $\left(\mathrm{V}_{\mathrm{t}}\right)$ was obtained at a relative pressure of approximately 0.99 . The mesopore volume $\left(\mathrm{V}_{\mathrm{me}}\right)$, micropore volume $\left(\mathrm{V}_{\mathrm{mi}}\right)$, and ultramicropore $(<0.7 \mathrm{~nm})$ volume $\left(\mathrm{V}_{<0.7 \mathrm{~nm}}\right)$ were obtained by adopting a non-local density functional theory (NLDFT) model, heterogeneous surface -2 dimensional-NLDFT (HS-2D-NLDFT), where $\mathrm{V}_{<0.7 \mathrm{~nm}}$ is part of $\mathrm{V}_{\mathrm{mi}}$. The median pore width $\left(\mathrm{d}_{\mathrm{HK}}\right)$ was obtained using the Horváth-Kawazoe (HK) method. The pore size distribution curves were also inferred from the HS-2D-NLDFT model.

\section{3. $\mathrm{CO}_{2}$ Adsorption Experiments}

The Micromeritics ASAP 2020 system was also used to measure the $\mathrm{CO}_{2}$ adsorption isotherms on the activated samples at 25,40 , and $55^{\circ} \mathrm{C}$ under a $\mathrm{CO}_{2}$ pressure of less than $123 \mathrm{kPa}$. The samples (approximately $0.05 \mathrm{~g}$ ) were outgassed at $350^{\circ} \mathrm{C}$ for $24 \mathrm{~h}$ for the removal of adsorbed contaminants prior to the measurement. The equilibration interval for each pressure point was set as $45 \mathrm{~s}$. A chiller dewar (Micromeritics) was utilized to replace the traditional dewar, which could be connected with a circulating water bath thermostat for the temperature control during the $\mathrm{CO}_{2}$ adsorption process.

The Freundlich equation [52], one of the most commonly used equations for adsorption isotherms, was adopted for the model fitting of the adsorption experimental data. The Freundlich adsorption isotherm is an empirical equation that assumes heterogeneous adsorption due to the diversity of adsorption sites, as shown in Equation (1):

$$
q_{e}=K_{F} P^{1 / n},
$$

where $q_{e}(\mathrm{mmol} / \mathrm{g})$ is the equilibrium adsorption capacity, $K_{F}\left((\mathrm{mmol} / \mathrm{g})(1 / \mathrm{kPa})^{1 / \mathrm{n}}\right)$ is the Freundlich adsorption coefficient, $P(\mathrm{kPa})$ is the gas pressure, and $n$ is a constant indicating the isotherm curvature. The parameter $n$ is usually greater than unity, and the larger the value of $n$ is the more favorable the adsorption is. In general, the values of parameters $n$ and $K_{F}$ both decrease with increasing temperature.

The isosteric heat of adsorption $\left(Q_{s t}\right)$ measures the change in enthalpy when adsorbate molecules are adsorbed from the bulk gas phase to the adsorbed phase [52]. It represents the interactions between the adsorbate molecules and the adsorbent lattice atoms and provides a measure of energetic heterogeneity for the gas-solid interfaces [53]. The Clausius-Clapeyron equation, as shown in Equation (2), was used to calculate the values of $Q_{s t}$ :

$$
-\frac{Q_{s t}}{R}=\left(\frac{d \ln P}{d \frac{1}{T}}\right),
$$

where $Q_{s t}(\mathrm{~kJ} / \mathrm{mol})$ is the isosteric heat of adsorption, $R(=8.314 \mathrm{~J} / \mathrm{mol} / \mathrm{K})$ is the gas constant, $P(\mathrm{kPa})$ is the $\mathrm{CO}_{2}$ pressure, and $T(\mathrm{~K})$ is the adsorption temperature. A schematic illustration of this study is shown in Scheme 1 , which includes electrospinning, stabilization, carbonization, activation, and $\mathrm{CO}_{2}$ adsorption. 


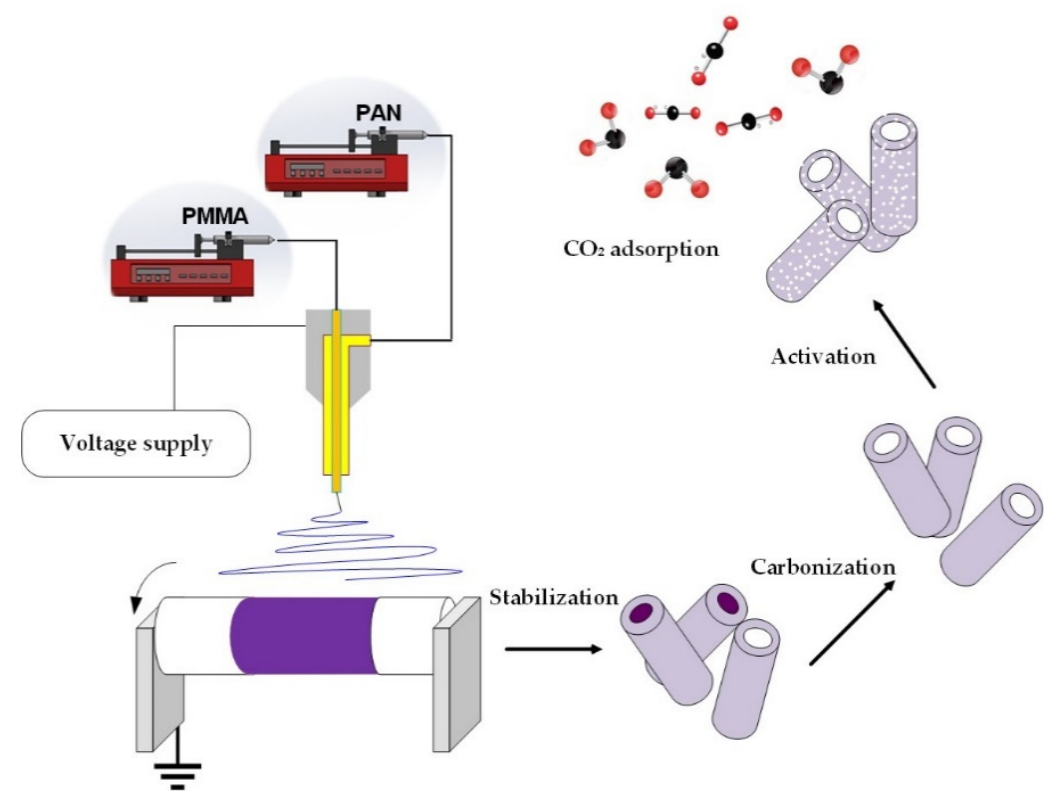

Scheme 1. Schematic illustration of this study, including electrospinning, stabilization, carbonization, activation, and $\mathrm{CO}_{2}$ adsorption.

\section{Results and Discussion}

\subsection{Field Emission Scanning Electron Microscopy (FESEM) Images}

Figure 1a-c show the FESEM micrographs of the cross-sectional areas for all the carbonized samples. These images clearly evidence the formation of hollow tubular structures. The shell material (PAN) was converted into a turbostratic carbon structure by thermal treatment at temperatures of $900{ }^{\circ} \mathrm{C}$ or above, whereas the sacrificial core component (PMMA) was decomposed. After activation, the samples could hold the hollow structures (Figure 1d-f). If a sacrificial core is decomposed at an early stage of the thermal treatment, the shell polymer of HACNFs will be subjected to severe shrinkage without any support; thus, the shapes of HACNFs may be distorted [54]. Although the thermal decomposition temperature of PMMA was below $300^{\circ} \mathrm{C}$ [55], the HACNFs prepared in this study did not appear to be out of shape, as seen from Figure 1. It was expected that the use of a slow heating rate $\left(1^{\circ} \mathrm{C} / \mathrm{min}\right)$ during the stabilization step could prevent the sacrificial core from evaporating too fast and thus preserve the shape of the shell component. Due to its immiscibility with PAN, PMMA was thought to be a suitable material for use as the sacrificial core for fabricating HACNFs. All nanofibers were randomly aligned along the winding direction of the drum collector. The outer and interior surfaces of hollow nanofibers were relatively smooth. The outer diameters of C900, C1000, and C1100 were approximately 725, 758, and $842 \mathrm{~nm}$, respectively, with a shell thickness of $100 \mathrm{~nm}$. For the activated samples, the outer diameters of A900-850, A1000-850, and A1100-850 were approximately 550, 605, and $750 \mathrm{~nm}$, respectively, with a shell thickness of about $75 \mathrm{~nm}$.

\subsection{Elemental Analysis (EA)}

The elemental compositions of $\mathrm{C}, \mathrm{H}$, and $\mathrm{N}$ atoms in the bulk phase of the samples are shown in Table 1. The most abundant nitrogen content was observed in C900 (8.0 wt.\%), in which the nitrogen was derived from the $\mathrm{C} \equiv \mathrm{N}$ bonding in a PAN precursor. As the carbonization temperature increased, the nitrogen content in the carbonized samples reduced rapidly. This implied that the carbonization process involved successive denitrogenation reactions, eventually resulting in partially graphitic structures. The activated samples had a similar behavior-i.e., the nitrogen content decreased with an increase in the carbonization temperature. Compared with the pair samples-i.e., the samples carbonized at the same temperature and with/without activation - the nitrogen contents went from decreasing (carbonized at $900{ }^{\circ} \mathrm{C}$ ) to increasing (carbonized at $1100^{\circ} \mathrm{C}$ ), which could be ascribed to 
the fact that the temperature of $\mathrm{CO}_{2}$ activation was lower than those of the carbonization temperature. The results indicated that the carbonization temperature played an important role in controlling the nitrogen content of the ACNFs.
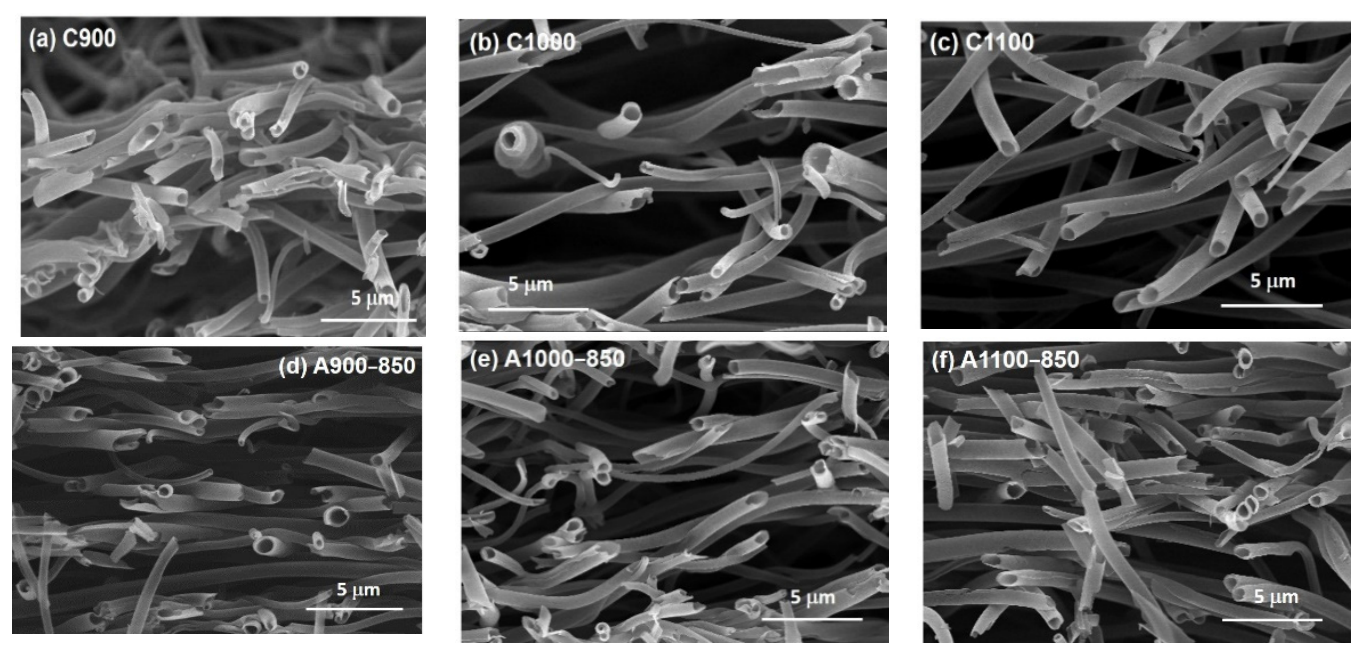

Figure 1. Field emission scanning electron microscopy (FESEM) images of the samples: (a) C900; (b) C1000; (c) C1100; (d) A900-850; (e) A1000-850; and (f) A1100-850.

Table 1. Elemental compositions from the elemental analysis (wt.\%) and XPS analysis (at.\%).

\begin{tabular}{cccccccc}
\hline \multirow{2}{*}{ Sample } & \multicolumn{3}{c}{ Elemental Analysis (wt.\%) } & \multicolumn{3}{c}{ XPS Analysis (at.\%) } \\
\cline { 2 - 7 } & $\mathbf{C}$ & $\mathbf{H}$ & $\mathbf{N}$ & Others & C 1 s & N 1 s & O 1 s \\
\hline C900 & 73.4 & 2.2 & 8.0 & 16.5 & 89.6 & 7.2 & 3.3 \\
C1000 & 78.4 & 2.2 & 3.6 & 15.8 & 93.2 & 3.3 & 3.6 \\
C1100 & 65.8 & 3.6 & 1.5 & 29.1 & 95.3 & 1.7 & 3.0 \\
A900-850 & 68.6 & 2.8 & 6.8 & 21.8 & 91.4 & 5.4 & 3.2 \\
A1000-850 & 64.6 & 3.5 & 3.6 & 28.2 & 92.6 & 3.1 & 4.3 \\
A1100-850 & 70.4 & 2.9 & 2.8 & 23.9 & 96.6 & 2.0 & 1.4 \\
\hline
\end{tabular}

\subsection{Fourier Transform Infrared (FTIR) Spectroscopy}

The FTIR spectra of the samples are shown in Figure 2a, and the patterns of C900 and A1000-850 are highlighted in Figure 2b,c, respectively. The bands in the regions $3000-2800 \mathrm{~cm}^{-1}, 2000-1800 \mathrm{~cm}^{-1}, 1410-1395 \mathrm{~cm}^{-1}$, and $820-790 \mathrm{~cm}^{-1}$ were assigned to the vibrations of aliphatic $\mathrm{C}-\mathrm{H}$ groups. The strong band at $1105 \mathrm{~cm}^{-1}$ was attributed to $\mathrm{C}-\mathrm{O}$ stretching vibrations. The characteristic absorbance peak at $1534 \mathrm{~cm}^{-1}$ was due to the $\mathrm{N}-\mathrm{H}$ bending and $\mathrm{N}-\mathrm{O}$ stretching vibrations. The bands at $3400-3200 \mathrm{~cm}^{-1}$ and $4000-3600 \mathrm{~cm}^{-1}$ were assigned to $\mathrm{N}-\mathrm{H}$ and $\mathrm{O}-\mathrm{H}$ stretching vibrations, respectively [56-58]. As seen in Figure 2a, the strength of the absorbance band at $1534 \mathrm{~cm}^{-1}$ was highly associated with the nitrogen contents (Table 1). Moreover, the increase in the number of defect sites of the graphite-like structure due to the incorporation of nitrogen atoms into the carbon lattices may result in the existing bands in the FTIR continuously shifting to higher frequencies (wavenumbers) [59]. 

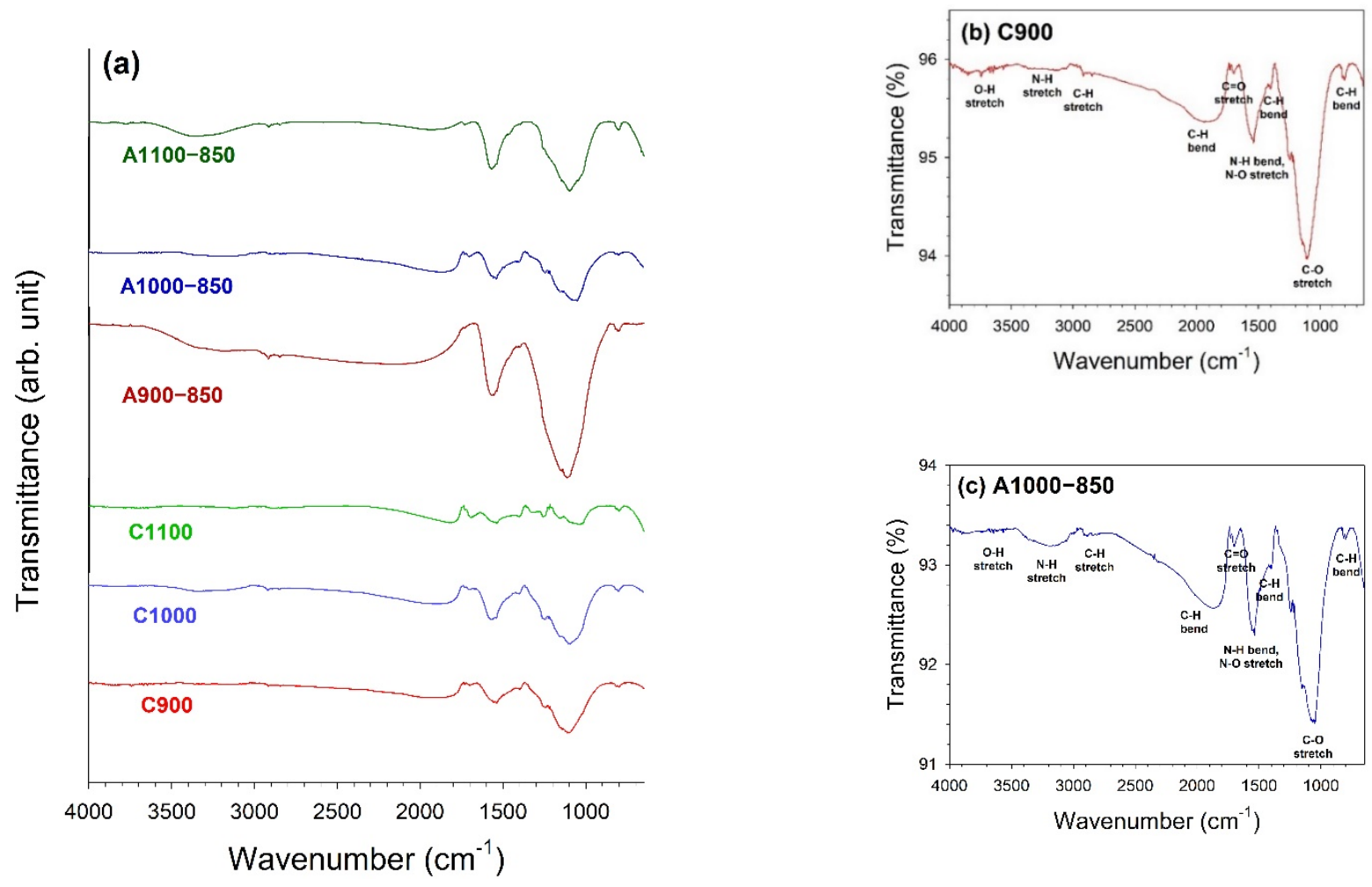

Figure 2. The FTIR spectra of the samples. (a) All samples, (b) C900, (c) A1000-850.

\subsection{X-ray Photoelectron Spectroscopy (XPS)}

The XPS was carried out to investigate the surface elemental compositions and their chemical states on the surfaces of the samples. The XPS survey scan spectra of the samples revealed that there were three major peaks, which were caused by the $\mathrm{C} 1 \mathrm{~s}, \mathrm{~N} 1 \mathrm{~s}$, and $\mathrm{O} 1 \mathrm{~s}$ photoelectrons. The atomic ratios of $\mathrm{C} 1 \mathrm{~s}, \mathrm{~N} 1 \mathrm{~s}$, and $\mathrm{O} 1 \mathrm{~s}$ on the surfaces are summarized in Table 1. Although the results of EA indicate the contents in the bulk phase and XPS data provide surface compositions, the trends for the nitrogen contents were very similar. The deconvolution of high-resolution XPS spectra over the C1s, O1s, and N1s regions for all samples was performed in order to comprehend the chemical bonding states.

Figure 3 shows the high-resolution XPS spectra of the samples in the $C$ 1s binding energy region. The profiles of the XPS C 1s peaks were not significantly changed whether the samples were carbonized at different temperatures or further activated. Table 2 shows the calculated percentages of non-functional and functional carbon atoms. The $C 1$ s spectra were decomposed into at most five identified components that represented carbon atoms due to aliphatic and aromatic backbones $(\mathrm{C}-\mathrm{C} / \mathrm{C}=\mathrm{C})$ at $285 \mathrm{eV}$ and carbon atoms present in $\mathrm{C}-\mathrm{N}(286.1 \mathrm{eV}), \mathrm{C}=\mathrm{N} / \mathrm{C}-\mathrm{OH}(286.6 \mathrm{eV}), \mathrm{C}=\mathrm{O}(287.6 \mathrm{eV})$, and $\mathrm{COOH}(290.5 \mathrm{eV})$ [60-63]. The $\mathrm{C}-\mathrm{C}$ and $\mathrm{C}=\mathrm{C}$ were the predominant groups for all samples. $\mathrm{C} 900$ contained much higher percentages of nitrogen-containing functional groups. However, when the carbonization temperature increased, the nitrogen groups significantly decreased. It is worth noting that $\mathrm{CO}_{2}$ activation contributed to the increase in the percentages of $\mathrm{C}=\mathrm{N}, \mathrm{C}-\mathrm{OH}$, and $\mathrm{C}=\mathrm{O}$. In addition, the percent of $\mathrm{COOH}$ in the samples remained very stable regardless of the treatment applied. 

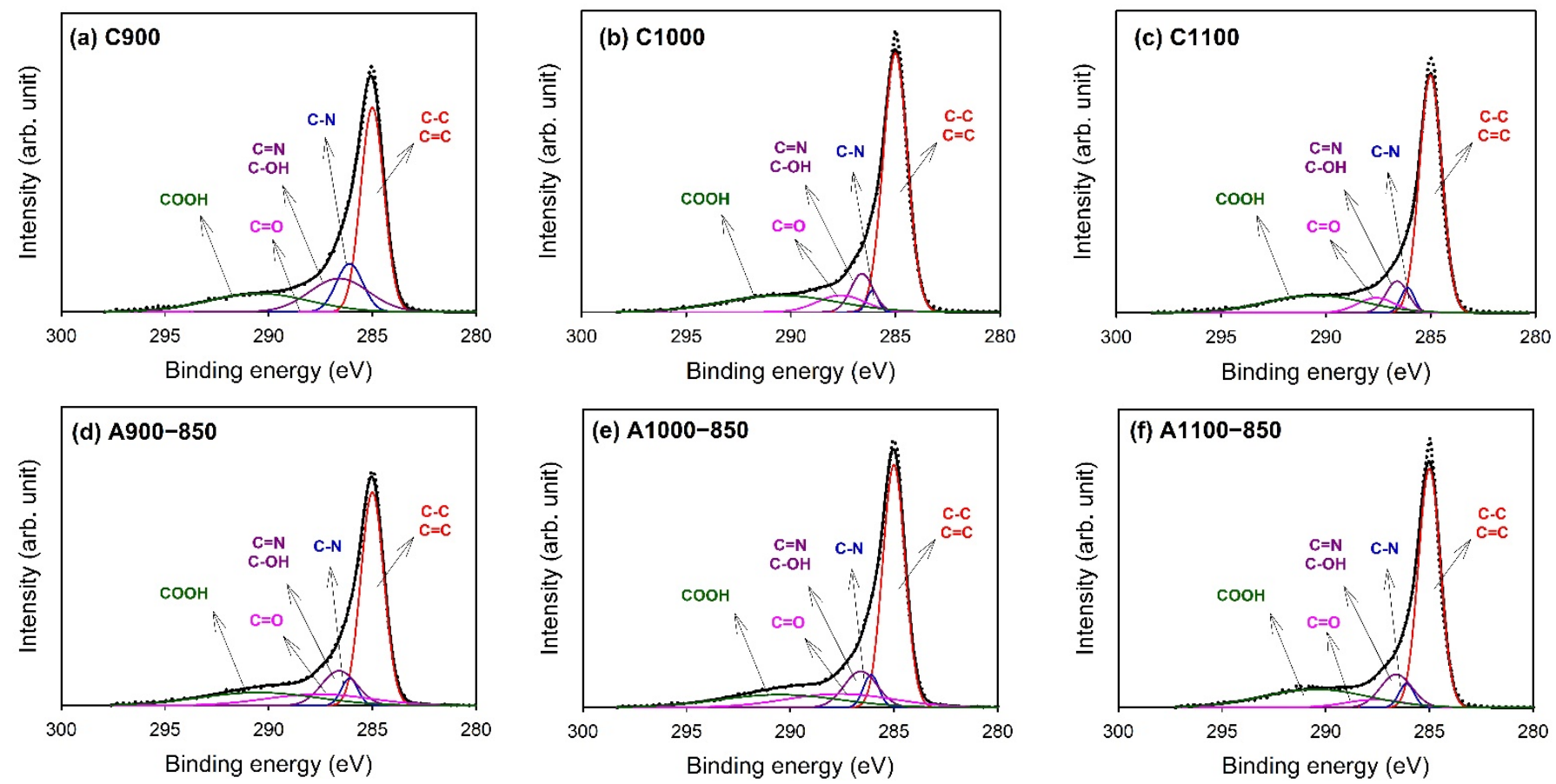

Figure 3. X-ray photoelectron spectroscopy (XPS) C 1s spectra: (a) C900; (b) C1000; (c) C1100; (d) A900-850; (e) A1000-850; and (f) A1100-850. The values are given in the atomic ratio (\%) of total intensity.

Table 2. Results of the fits of the XPS C 1s region, values given in at.\% (percent of total intensity).

\begin{tabular}{cccccccc}
\hline $\begin{array}{c}\text { Binding Energy } \\
(\mathbf{e V})\end{array}$ & Type & C900 & C1000 & C1100 & A900-850 & A1000-850 & A1100-850 \\
\hline 285 & $\mathrm{C}-\mathrm{C} / \mathrm{C}=\mathrm{C}$ & 43.2 & 58.0 & 58.8 & 48.2 & 49.4 & 56.0 \\
& & $(48)$ & $(62)$ & $(62)$ & $(53)$ & $(53)$ & $(58)$ \\
286.1 & $\mathrm{C}-\mathrm{N}$ & 11.6 & 2.2 & 3.8 & 4.4 & 4.6 & 3.8 \\
& & $(13)$ & $(2)$ & $(4)$ & $(5)$ & $(5)$ & $(4)$ \\
286.6 & $\mathrm{C}=\mathrm{N} / \mathrm{C}-\mathrm{OH}$ & 17.9 & 8.0 & 7.7 & 12.0 & 11.0 & 11.2 \\
& & $(20)$ & $(9)$ & $(8)$ & $(13)$ & $(12)$ & $(12)$ \\
287.6 & $\mathrm{C}=\mathrm{O}$ & - & 7.4 & 6.2 & 11.7 & 13.4 & 5.0 \\
& & $(0)$ & $(8)$ & $(6)$ & $(13)$ & $(14)$ & $(5)$ \\
290.5 & $-\mathrm{COOH}$ & 16.9 & 17.6 & 18.9 & 15.2 & 14.2 & 20.6 \\
& & $(19)$ & $(19)$ & $(20)$ & $(17)$ & $(15)$ & $(21)$ \\
\hline
\end{tabular}

The results of the fits of the XPS N 1s spectra [63-66] are illustrated in Figure 4. The spectra demonstrate that carbonization and activation had evident influences on the $\mathrm{N}$ 1 s peaks, which are characterized by a bimodal pattern. As seen in Figure 4, the peak at $398.4 \mathrm{eV}$ was less stable than the other one at $401.2 \mathrm{eV}$. That means that functional groups with lower binding energies had a higher tendency to unbind from the surface when the samples were treated at high temperatures. The calculated percentages of functional nitrogen atoms are presented in Table 3. Four functional groups at 398.4, 400.5, 401.2, and $404.6 \mathrm{eV}$ were resolved; these can be assigned to $\mathrm{C}=\mathrm{N}, \mathrm{O}=\mathrm{C}-\mathrm{NH}$, quaternary or protonated $\mathrm{N}$, and oxidized species. For the samples of C1100 and A1100-850, the quaternary or protonated $\mathrm{N}$ was shifted to $401.5 \mathrm{eV}$. No peak for $\mathrm{NH}_{2}(399-399.3 \mathrm{eV})$ was resolved. The major functionalities of most samples were $\mathrm{O}=\mathrm{C}-\mathrm{NH}$ and quaternary or protonated $\mathrm{N}$, except for A900-850, which possessed a higher percentage of $\mathrm{C}=\mathrm{N}$ groups. The quaternary or protonated $\mathrm{N}$ was believed to be caused by the precursor of the carbon nanofibers (PAN). 

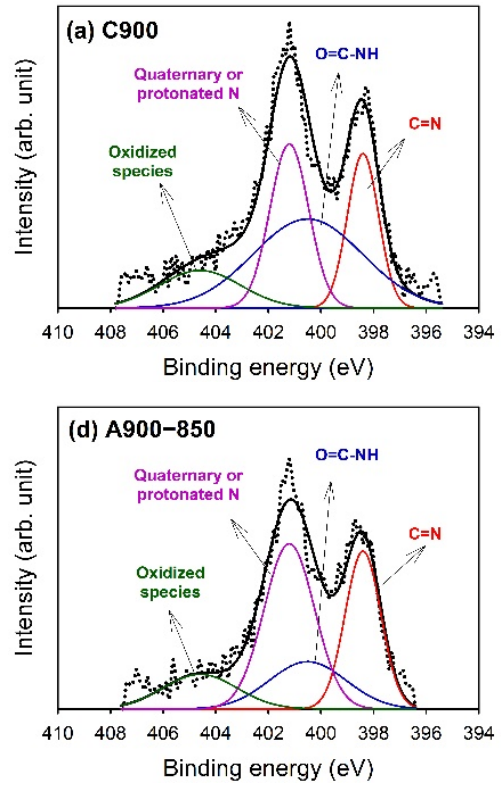
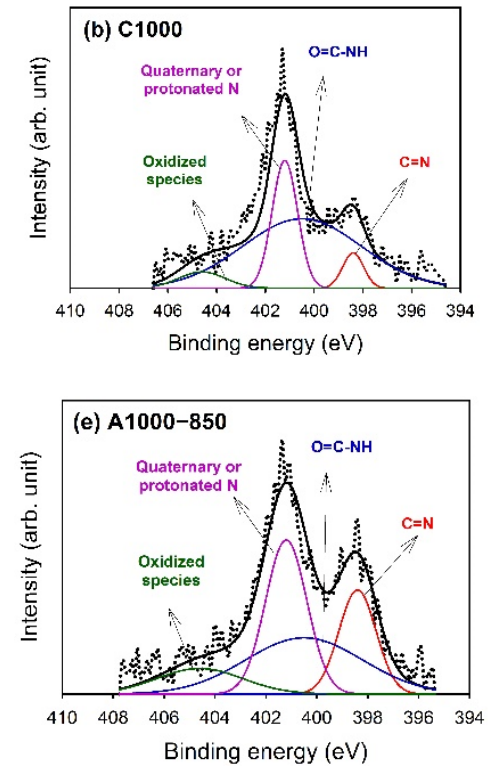
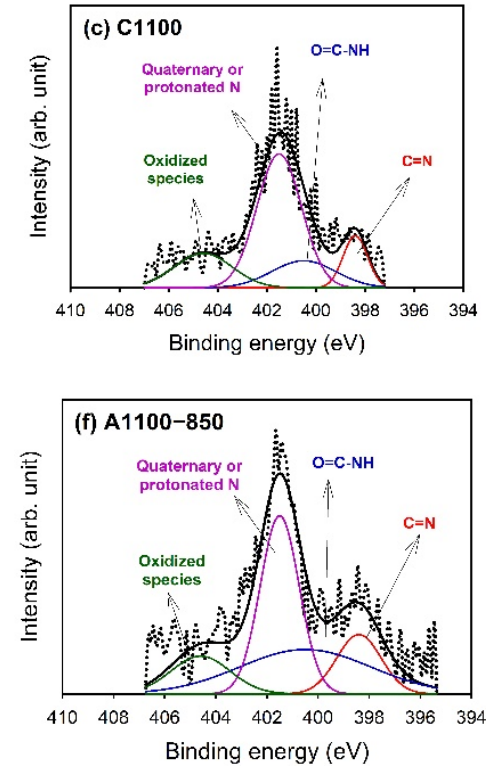

Figure 4. X-ray photoelectron spectroscopy (XPS) N 1 s spectra: (a) C900; (b) C1000; (c) C1100; (d) A900-850; (e) A1000-850; and (f) A1100-850. The values are given in an atomic ratio (\%) of total intensity.

Table 3. Results of the fits of the XPS N 1s region, values given in at.\% (percent of total intensity).

\begin{tabular}{cccccccc}
\hline Binding Energy (eV) & Type & C900 & C1000 & C1100 & A900-850 & A1000-850 & A1100-850 \\
\hline \multirow{3}{*}{398.4} & $\mathrm{~N}=\mathrm{C}$ & 1.4 & 0.2 & 0.2 & 1.5 & 0.6 & 0.3 \\
& & $(20)$ & $(6)$ & $(12)$ & $(28)$ & $(20)$ & $(15)$ \\
400.5 & $\mathrm{O}=\mathrm{C}-\mathrm{NH}$ & 2.9 & 2.1 & 0.3 & 1.0 & 1.1 & 0.7 \\
& Quaternary or & $(41)$ & $(63)$ & $(16)$ & $(18)$ & $(35)$ & $(33)$ \\
401.2 & 1.91 & 0.83 & 0.93 & 2.24 & 1.04 & 0.79 \\
& protonated N & $(27)$ & $(25)$ & $(55)$ & $(41)$ & $(33)$ & $(39)$ \\
404.6 & Oxidized species & 0.9 & 0.2 & 0.3 & 0.7 & 0.4 & 0.3 \\
& & $(13)$ & $(6)$ & $(18)$ & $(13)$ & $(12)$ & $(13)$ \\
\hline
\end{tabular}

Additional information on the nature of surface oxygen-containing functional groups might be provided from the deconvolution of the XPS O $1 \mathrm{~s} \mathrm{spectra} \mathrm{(Figure} \mathrm{5).} \mathrm{Compared}$ with the XPS N 1 s peaks, the effect of treatments on the XPS O $1 \mathrm{~s}$ spectra represented different patterns. The carbonization temperature only had a subtle effect on the shape of the spectra; however, the $\mathrm{CO}_{2}$ activation generated many more oxygen-containing functional groups at higher binding energies. Table 4 displays the atomic percentages of oxygen-containing functional groups $[61,62,67]$. The fitting revealed the presence of three surface oxides, including the $\mathrm{C}=\mathrm{O} / \mathrm{O}=\mathrm{C}-\mathrm{N}(531.5 \mathrm{eV}), \mathrm{C}-\mathrm{OH}(532.7 \mathrm{eV})$, and $\mathrm{COOH}$ $(533.7 \mathrm{eV})$ groups. As seen from the data, the major oxygen groups on the carbonized samples were the $\mathrm{C}=\mathrm{O} / \mathrm{O}=\mathrm{C}-\mathrm{N}$ and $\mathrm{COOH}$ groups. However, the $\mathrm{C}=\mathrm{O} / \mathrm{O}=\mathrm{C}-\mathrm{N}$ and $\mathrm{C}-$ $\mathrm{OH}$ groups were released significantly after activation; hence, the primary oxygen groups on activated samples were only $\mathrm{COOH}$ groups.

\section{5. $\mathrm{N}_{2}$ Adsorption-Desorption Isotherms}

The $\mathrm{N}_{2}$ adsorption-desorption isotherms of the samples at $-196{ }^{\circ} \mathrm{C}$ are shown in Figure 6, in which the carbonized and activated samples are given for comparison. Regardless of whether the samples were carbonized or activated, the $\mathrm{N}_{2}$ adsorption isotherms were essentially type I according to the Brunauer-Emmett-Teller (BET) classification. There were no significant hysteresis loops, which indicated their microporous character. Capillary condensation was observed at relative pressures approaching 1.0, which could be due to the space where the nanofibers were intertwined. As seen from Figure 4, the $\mathrm{N}_{2}$ adsorption amounts were proportional to the carbonization temperature. Moreover, the $\mathrm{N}_{2}$ adsorption amounts were considerably improved after activation. 

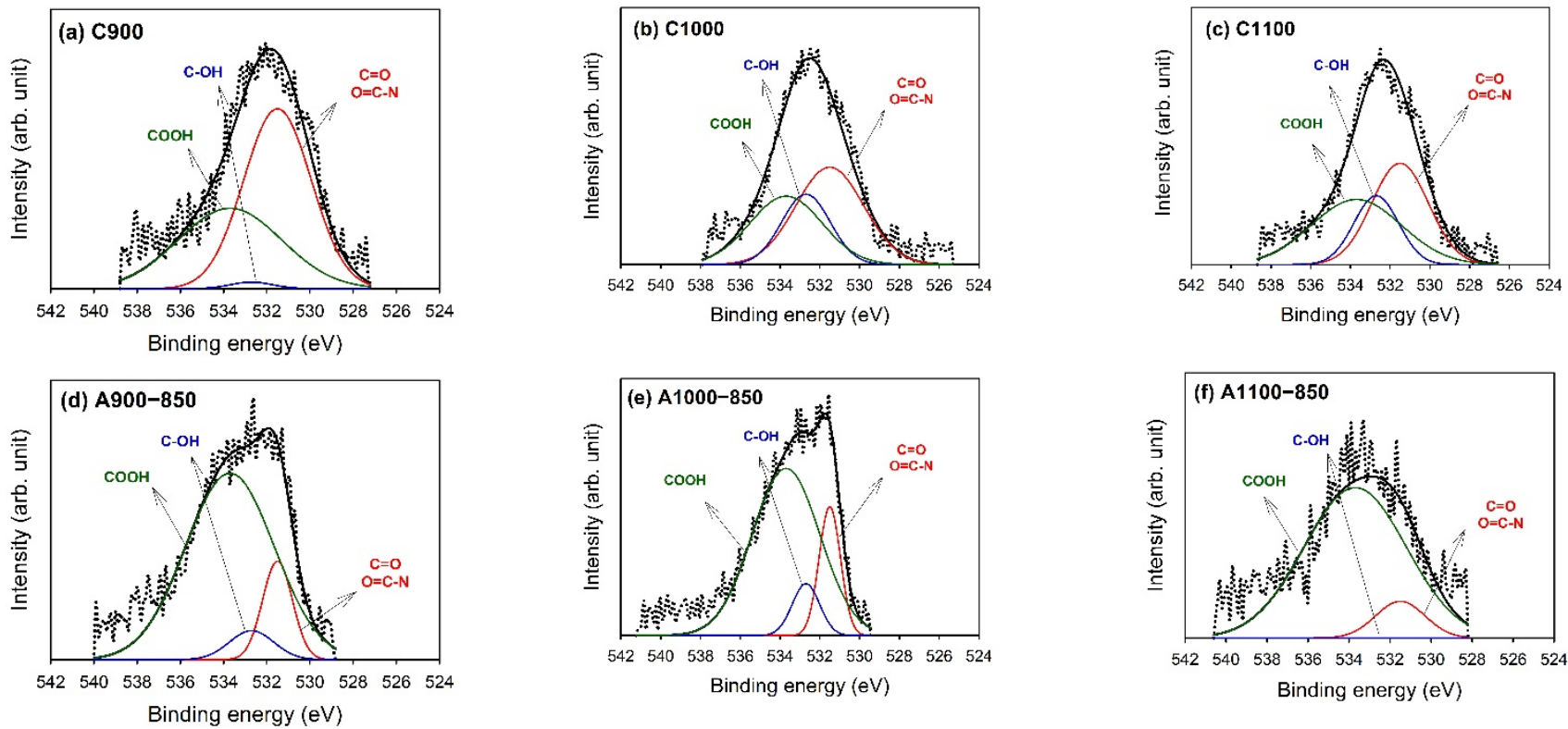

Figure 5. X-ray photoelectron spectroscopy (XPS) O 1 s spectra: (a) C900; (b) C1000; (c) C1100; (d) A900-850; (e) A1000-850; and (f) A1100-850. The values are given in an atomic ratio (\%) of total intensity.

Table 4. Results of the fits of the XPS O $1 \mathrm{~s}$ region, values given in at\% (percent of total intensity).

\begin{tabular}{cccccccc}
\hline $\begin{array}{c}\text { Binding Energy } \\
(\mathbf{e V})\end{array}$ & Type & C900 & C1000 & C1100 & A900-850 & A1000-850 & A1100-850 \\
\hline 531.5 & $\mathrm{C}=\mathrm{O} / \mathrm{O}=\mathrm{C}-\mathrm{N}$ & 1.3 & 1.6 & 1.2 & 0.5 & 0.8 & 0.1 \\
& & $(38)$ & $(44)$ & $(39)$ & $(14)$ & $(18)$ & $(11)$ \\
532.7 & $\mathrm{C}-\mathrm{OH}$ & 0.3 & 0.8 & 0.6 & 0.2 & 0.4 & - \\
& & $(9)$ & $(23)$ & $(21)$ & $(6)$ & $(9)$ & $(0)$ \\
533.7 & $\mathrm{COOH}$ & 1.7 & 1.2 & 1.2 & 2.5 & 3.1 & 1.3 \\
& & $(53)$ & $(33)$ & $(40)$ & $(80)$ & $(73)$ & $(89)$ \\
\hline
\end{tabular}

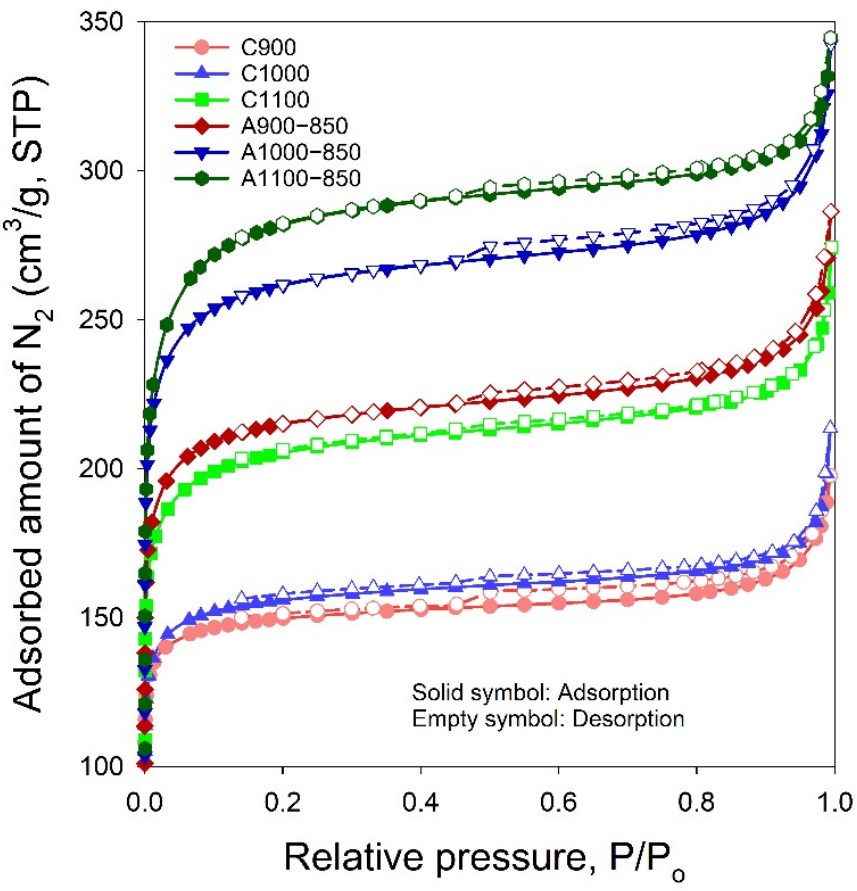

Figure 6. $\mathrm{N}_{2}$ adsorption-desorption isotherms at $-196{ }^{\circ} \mathrm{C}$ for all samples.

The surface structure properties of the samples determined from the $\mathrm{N}_{2}$ adsorptiondesorption isotherms are shown in Table 5. The BET specific surface area (SSA), micropore 
surface area $\left(\mathrm{S}_{\mathrm{mi}}\right)$, total pore volume $\left(\mathrm{V}_{\mathrm{t}}\right)$, and micropore volume $\left(\mathrm{V}_{\mathrm{mi}}\right)$ were increased with respect to the carbonization temperatures. Moreover, the subsequent activation could conspicuously improve these properties. However, the ultramicropore (pore size less than $0.7 \mathrm{~nm}$ ) volumes showed a different trend. Except for the ratio of $\mathrm{V}_{\mathrm{mi}}$ to $\mathrm{V}_{\mathrm{t}}$, the ratios of $\mathrm{S}_{\mathrm{mi}} / \mathrm{SSA}, \mathrm{V}_{<0.7 \mathrm{~nm}} / \mathrm{V}_{\mathrm{t}}$, and $\mathrm{V}_{<0.7 \mathrm{~nm}} / \mathrm{V}_{\mathrm{mi}}$ were decreased with increasing carbonization temperatures. This suggested that a higher carbonization temperature would lead to a lower microporosity for the HACNFs. There was a significant reduction in the ratios of $\mathrm{V}_{<0.7 \mathrm{~nm}} / \mathrm{V}_{\mathrm{t}}$ and $\mathrm{V}_{<0.7 \mathrm{~nm}} / \mathrm{V}_{\mathrm{mi}}$ after activation. It was believed that $\mathrm{CO}_{2}$ activation could partially oxidize the carbon atoms and that these carbon oxides might evaporate, thus generating more micropores and inducing pore enlargement. This could be proven from the median pore width shown in Table 5 . Therefore, the pore volumes increased but the microporosity fell off.

Table 5. Surface features of the samples determined from the $\mathrm{N}_{2}$ adsorption-desorption isotherms at $-196{ }^{\circ} \mathrm{C}$.

\begin{tabular}{|c|c|c|c|c|c|c|c|c|c|c|c|c|}
\hline Sample & $\begin{array}{l}\operatorname{SSA}^{\alpha} \\
\left(\mathrm{m}^{2} / \mathrm{g}\right)\end{array}$ & $\begin{array}{l}S_{m i} \beta \\
\left(m^{2} / g\right)\end{array}$ & $\begin{array}{c}V_{t}^{\gamma} \\
\left(\mathrm{cm}^{3} / g\right)\end{array}$ & $\begin{array}{l}\mathrm{V}_{\mathrm{ma}} \varphi \\
\left(\mathrm{cm}^{3} / \mathrm{g}\right)\end{array}$ & $\begin{array}{c}V_{\text {me }} \eta \\
\left(\mathrm{cm}^{3} / \mathrm{g}\right)\end{array}$ & $\begin{array}{c}V_{m i}{ }^{\eta} \\
\left(\mathrm{cm}^{3} / g\right)\end{array}$ & $\begin{array}{c}\mathrm{V}_{<0.7 \mathrm{~nm}} \eta \\
\left(\mathrm{cm}^{3} / \mathrm{g}\right)\end{array}$ & $\underset{(\mathrm{nm})}{\mathrm{d}_{\mathrm{HK}}{ }^{\varepsilon}}$ & $\mathrm{S}_{\mathrm{mi}} / \mathrm{SSA}$ & $\mathrm{V}_{\mathrm{mi}} / \mathrm{V}_{\mathrm{t}}$ & $\mathrm{V}_{<0.7 \mathrm{~nm}} / \mathrm{V}_{\mathrm{t}}$ & $\mathrm{V}_{<0.7 \mathrm{~nm}} / \mathrm{V}_{\mathrm{mi}}$ \\
\hline C900 & 502 & 434 & 0.3057 & 0.0192 & 0.0497 & 0.2368 & 0.2170 & 1.35 & 0.86 & 0.77 & 0.71 & 0.92 \\
\hline C1000 & 524 & 441 & 0.3303 & 0.0379 & 0.0518 & 0.2406 & 0.2059 & 1.43 & 0.84 & 0.73 & 0.62 & 0.86 \\
\hline C1100 & 696 & 558 & 0.4244 & 0.0458 & 0.0631 & 0.3155 & 0.2360 & 1.50 & 0.80 & 0.74 & 0.56 & 0.75 \\
\hline A900-850 & 725 & 597 & 0.4429 & 0.0360 & 0.0695 & 0.3374 & 0.1979 & 1.49 & 0.82 & 0.76 & 0.45 & 0.59 \\
\hline A1000-850 & 883 & 714 & 0.5297 & 0.0428 & 0.0783 & 0.4086 & 0.2185 & 1.55 & 0.81 & 0.77 & 0.41 & 0.53 \\
\hline A1100-850 & 954 & 734 & 0.5331 & 0.0428 & 0.0563 & 0.4340 & 0.2148 & 1.62 & 0.77 & 0.81 & 0.40 & 0.49 \\
\hline
\end{tabular}

${ }^{\alpha}$ SSA (specific surface area) was determined by the BET method. ${ }^{\beta} \mathrm{S}_{\mathrm{mi}}$ was determined by the $\mathrm{t}$-plot method. ${ }^{\gamma} \mathrm{V}_{\mathrm{t}}$ represented the single point total pore volume at $\mathrm{P} / \mathrm{P}_{\mathrm{o}} \approx 0.99 .{ }^{\eta} \mathrm{V}_{\mathrm{me}}, \mathrm{V}_{\mathrm{mi}}$, and $\mathrm{V}_{<0.7 \mathrm{~nm}}$ were determined by a non-local density functional theory (NLDFT) model. ${ }^{\varphi} \mathrm{V}_{\mathrm{ma}}$ was obtained by subtraction. ${ }^{\xi} \mathrm{d}_{\mathrm{HK}}$ was the median pore width obtained by the Horváth-Kawazoe (HK) method.

Figure 7 illustrates the pore size distributions in the $0.4-2 \mathrm{~nm}$ range identified from the HS-2D-NLDFT model. The main micropores for all samples were at approximately $0.55-0.65 \mathrm{~nm}$. The activation of C900 and 1000 enabled the pore size distribution to extend to smaller pore sizes. The pore size distributions shown in Figure 7 echoed the results shown in Table 5.

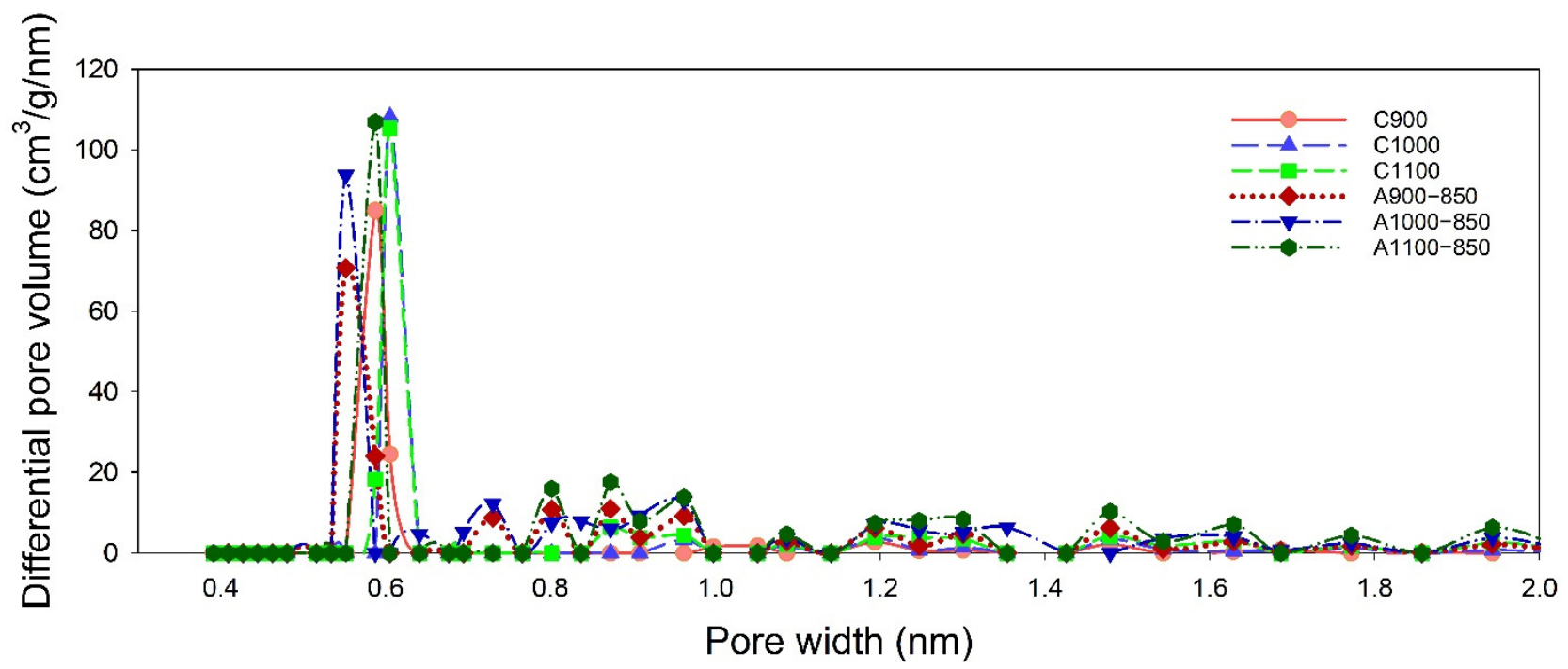

Figure 7. Pore size distributions of the samples, derived from the $\mathrm{N}_{2}$ adsorption isotherms at $-196^{\circ} \mathrm{C}$ by the NLDFT model.

\section{6. $\mathrm{CO}_{2}$ Adsorption}

Figure 8 displays the adsorption isotherms of $\mathrm{CO}_{2}$ on the HACNFs under a pressure less than $123 \mathrm{kPa}$ at different temperatures $\left(25,40\right.$, or $\left.55^{\circ} \mathrm{C}\right)$. For each measurement point, an equilibrium time of $45 \mathrm{~s}$ was maintained after achieving the set pressure value. As seen from Figure $8 \mathrm{a}-\mathrm{c}$, the $\mathrm{CO}_{2}$ uptakes increased with increasing pressure and decreasing temperature. The temperature dependence of the $\mathrm{CO}_{2}$ adsorption capacity in the range from 25 to $55{ }^{\circ} \mathrm{C}$ on the HACNF samples was consistent with the features of the exothermic reactions. The adsorption performance of $\mathrm{CO}_{2}$ followed the order 
A900-850 (3.03 mmol $/ \mathrm{g})>$ A1000-850 (2.96 mmol $/ \mathrm{g})>$ A1100-850 (2.06 mmol $/ \mathrm{g})$ at $25^{\circ} \mathrm{C}$ and $1 \mathrm{~atm}$. At $25^{\circ} \mathrm{C}$ and $0.15 \mathrm{~atm}$ (a typical untreated flue gas composition), the $\mathrm{CO}_{2}$ adsorption capacities had the same order-i.e., A900-850 (0.99 mmol/g) > A1000-850 $(0.84 \mathrm{mmol} / \mathrm{g})>$ A1100-850 (0.63 mmol $/ \mathrm{g})$.
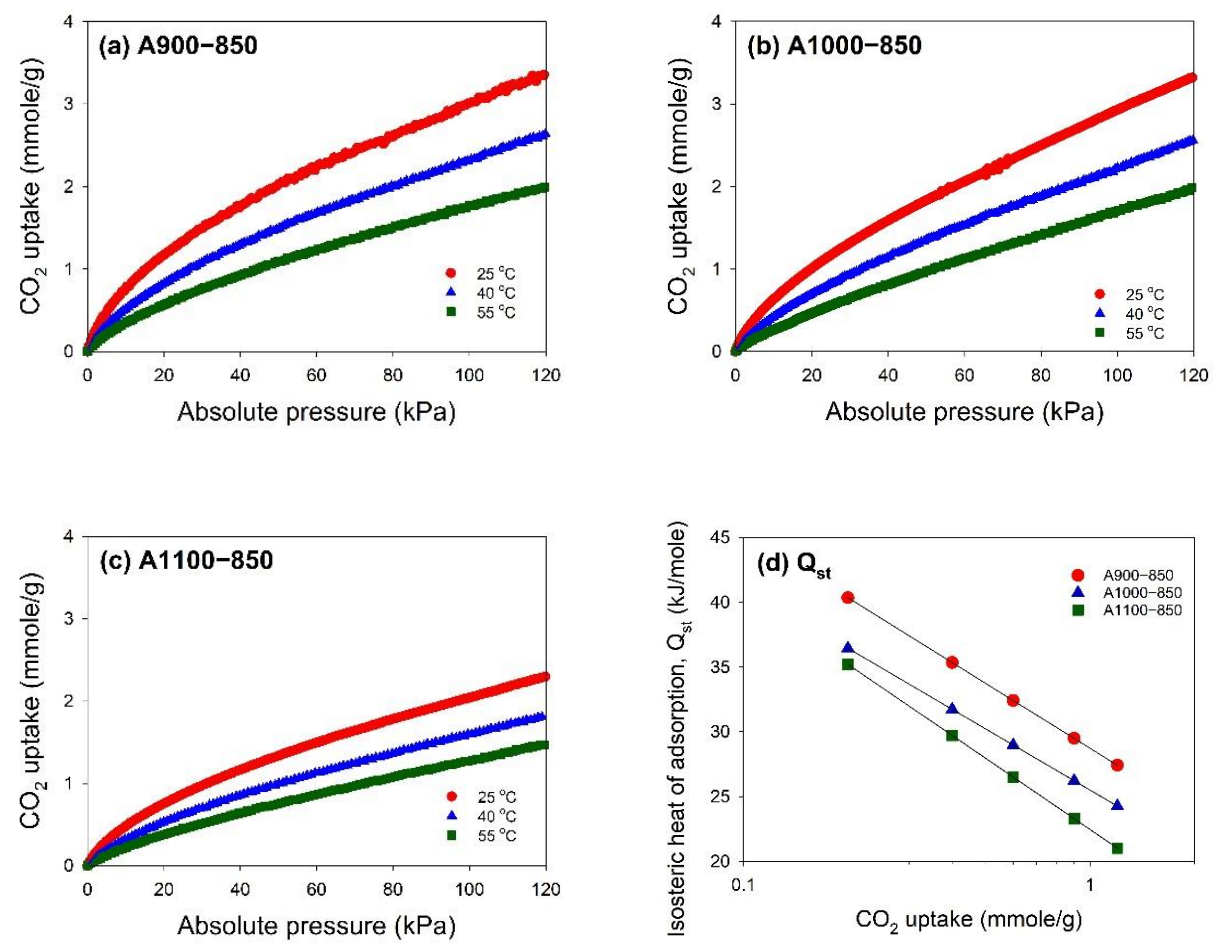

Figure 8. Adsorption isotherms of $\mathrm{CO}_{2}$ of the samples: (a) A900-850; (b) A1000-850; (c) A1100-850; and (d) the isosteric heat of adsorption of $\mathrm{CO}_{2}$ on the samples.

It is generally believed that the Lewis-base on the surface of adsorbents could improve their $\mathrm{CO}_{2}$ uptakes, as $\mathrm{CO}_{2}$ is regarded as a weak Lewis acidic gas. In addition, the electrondonor properties induced by the nitrogen-containing functional groups could attract the $\mathrm{CO}_{2}$ molecules towards the adsorbents [7,68-70]. Specifically, the imines and amines groups are usually regarded as the Lewis base and could generate distinct interactions with $\mathrm{CO}_{2}$ molecules. Among the activated samples in this study, A900-850 featured the highest bulk nitrogen content (6.8 wt.\%) and surface nitrogen groups (5.4 at.\%). As seen in Table 3, the atomic percentages of $\mathrm{N}=\mathrm{C}$ (imines or pyridine-type $\mathrm{N}$ ) and quaternary or protonated $\mathrm{N}$ (amines) groups on the activated samples were highly associated with their $\mathrm{CO}_{2}$ uptakes. These two functional groups could be responsible for the high $\mathrm{CO}_{2}$ adsorption capacities of A900-850. The nitrogen atom in pyridonic $\mathrm{N}(\mathrm{O}=\mathrm{C}-\mathrm{NH})$ is believed to be surrounded with a higher electron density and behave as a strong Lewis base [69]. However, it was found to be reactive during the $\mathrm{CO}_{2}$ activation process. Therefore, it could not be the essential functional groups.

Figure $8 \mathrm{~d}$ shows the variation in the $\mathrm{Q}_{\mathrm{st}}$ values with the $\mathrm{CO}_{2}$ loading, in which the $\mathrm{Q}_{\text {st }}$ values log-linearly decreased with the $\mathrm{CO}_{2}$ loading from 0.2 to $1.2 \mathrm{mmol} / \mathrm{g}$, indicating that the adsorption active sites on the surface of HACNFs were energetically heterogeneous for $\mathrm{CO}_{2}$ capture [71]. The $\mathrm{CO}_{2}$ adsorption on HACNFs was assigned to a typical physical adsorption according to $\mathrm{Q}_{\text {st }}$ values lower than $40 \mathrm{~kJ} / \mathrm{mol}$. The interactions between $\mathrm{CO}_{2}$ molecules and the nitrogen-containing functional groups or the enhanced micropore confinement [72] could be responsible for the higher $\mathrm{Q}_{\text {st }}$ values at a lower $\mathrm{CO}_{2}$ loading. Absolute values of the slope in the log-linear plot followed the order A1100-850 > A900-850 > A1000-850. This implied that the values of adsorption enthalpy were closer at low $\mathrm{CO}_{2}$ loadings for all samples, where the surface chemistry or ultramicroporosity controlled the adsorption performance, while the enthalpy decreased gradually when the 
$\mathrm{CO}_{2}$ loading grew, where the pore sizes might be the predominant factor affecting the $\mathrm{CO}_{2}$ uptakes.

In this study, the Freundlich equation was adopted to curve-fit the equilibrium adsorption data; the results are plotted in Figure 8a-c and summarized in Table 6. As seen from the data, the values of $K_{F}$ varied inversely proportional to the adsorption temperature as well as the carbonization temperature. However, the values of parameter $n$ presented a different character. The values of $n$ still decreased with increasing adsorption temperatures, but the least values of $n$ occurred at A1000-850, which was responsible for the lowest slope obtained in the discussion about $Q_{s t}$. Nevertheless, the values of $n$ ranged from 1.69 to 1.24 and were indicative of feasible adsorption. Table 7 summarized the $\mathrm{CO}_{2}$ uptakes for the adsorbents in this study and various support materials using electrospinning in the literature, which implied that the $\mathrm{CO}_{2}$ adsorption for the HACNFs prepared in this study were comparable or superior to those of other ACNFs.

Table 6. Fitted results of Freundlich equation for the $\mathrm{CO}_{2}$ adsorption data for the samples at different temperatures.

\begin{tabular}{ccccc}
\hline Sample & Temperature $\left({ }^{\circ} \mathbf{C}\right)$ & $\mathbf{K}_{\mathbf{F}}\left(\mathbf{m m o l} / \mathbf{g} / \mathbf{k P a}{ }^{\mathbf{1} / \mathbf{n}}\right)$ & $\mathbf{n}$ & $\mathbf{R}^{\mathbf{2}}$ \\
\hline \multirow{3}{*}{ A900-850 } & 25 & 0.1988 & 1.69 & 0.9994 \\
& 40 & 0.1186 & 1.55 & 0.9997 \\
& 55 & 0.0700 & 1.43 & 0.9999 \\
\multirow{3}{*}{ A1000-850 } & 25 & 0.1333 & 1.49 & 0.9997 \\
& 40 & 0.0791 & 1.38 & 0.9998 \\
& 55 & 0.0414 & 1.24 & 0.9999 \\
A1100-850 & 25 & 0.1166 & 1.61 & 0.9998 \\
& 40 & 0.0666 & 1.45 & 0.9998 \\
& 55 & 0.0385 & 1.31 & 0.9999 \\
\hline
\end{tabular}

Table 7. Comparisons of $\mathrm{CO}_{2}$ uptakes on the adsorbents in this study with various support materials using electrospinning in the literature.

\begin{tabular}{|c|c|c|c|c|c|c|}
\hline Adsorbent & Precursor & $\mathrm{S}_{\mathrm{BET}}\left(\mathrm{m}^{2} / \mathrm{g}\right)$ & Conc. of $\mathrm{CO}_{2}$ & Temp. $\left({ }^{\circ} \mathrm{C}\right)$ & $\mathrm{CO}_{2}$ Uptake (mmol/g) & Reference \\
\hline Hollow ACNF & PAN & 725 & $\begin{array}{c}1 \mathrm{~atm} \\
0.15 \mathrm{~atm}\end{array}$ & 25 & $\begin{array}{l}3.03 \\
0.99\end{array}$ & This study \\
\hline Hollow ACNF & PAN & 884 & $\begin{array}{c}1 \mathrm{~atm} \\
0.15 \mathrm{~atm}\end{array}$ & 25 & $\begin{array}{l}3.16 \\
0.94\end{array}$ & [73] \\
\hline $\mathrm{ACNF}$ & PAN & 362 & 1 bar & 25 & 2.37 & [50] \\
\hline $\mathrm{ACNF}$ & PAN & 872 & $\begin{array}{c}1 \mathrm{~atm} \\
0.15 \mathrm{~atm}\end{array}$ & 25 & $\begin{array}{l}3.47 \\
1.01\end{array}$ & [74] \\
\hline $\mathrm{ACNF}$ & PAN & 897 & $\begin{array}{c}1 \mathrm{~atm} \\
0.15 \mathrm{~atm}\end{array}$ & 25 & $\begin{array}{l}3.17 \\
1.00\end{array}$ & [75] \\
\hline ACNF & PAN & 486 & $\begin{array}{c}1 \text { bar } \\
0.15 \text { bar }\end{array}$ & 25 & $\begin{array}{l}2.25 \\
1.09\end{array}$ & [76] \\
\hline $\mathrm{ACNF}$ & PAN, polyvinylidene fluoride & 925 & 1 bar & 25 & 2.21 & [77] \\
\hline ACNF & PAN & 412 & $1 \mathrm{bar}$ & 25 & 0.92 & [78] \\
\hline ACNF & PAN Melamine & 547 & 1 bar & 25 & 1.44 & [78] \\
\hline
\end{tabular}

The cyclic regeneration of the adsorbents is an important property for evaluating their potential industrial applications. Therefore, 10 cyclic runs of the $\mathrm{CO}_{2}$ adsorptiondesorption process were carried out on the adsorbent A900-850. Figure 9a shows the ten-cycle results of the adsorption-desorption experiments for the $\mathrm{CO}_{2}$ at $25^{\circ} \mathrm{C}$. Within each cycle, the adsorbents were desorbed by subjecting to the conditions of a dynamic vacuum. The variation in the adsorption capacities for $\mathrm{CO}_{2}$ at $\mathrm{A} 900-850$ are displayed in Figure $9 \mathrm{~b}$, and the degradation of the $\mathrm{CO}_{2}$ uptakes after 10 cyclic runs could be held within $8.9 \%$. 

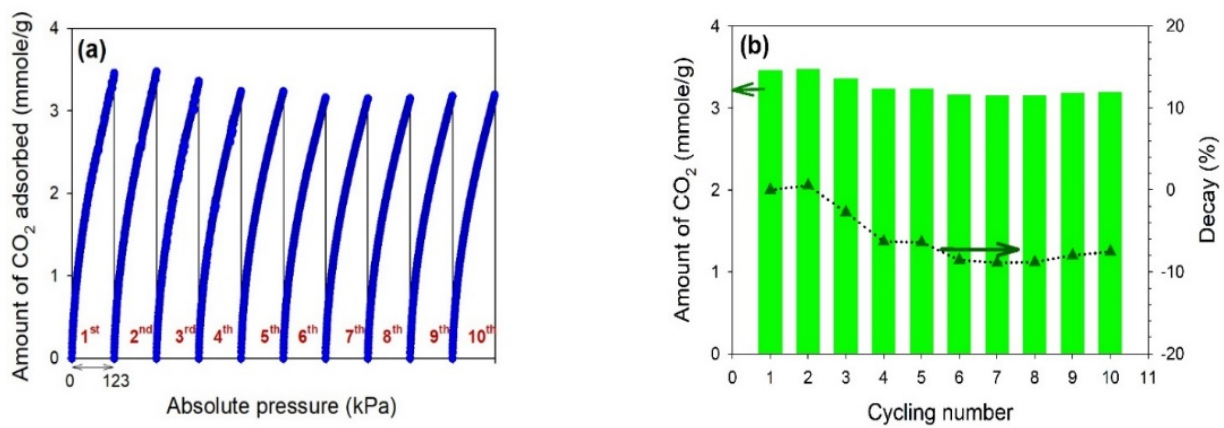

Figure 9. (a) Successive 10 cyclic adsorption tests and (b) the variation in the $\mathrm{CO}_{2}$ adsorption capacities at $123 \mathrm{kPa}$.

\section{Conclusions}

Coaxial electrospinning followed by stabilization, carbonization, and activation has been successfully used to fabricate HACNFs with a hollow tubular structure. The HACNFs were smooth on the surface and inside the wall, with outer diameters ranging from 550 to $750 \mathrm{~nm}$ and a shell thickness of $75 \mathrm{~nm}$. The carbonization temperature played an important role in controlling the nitrogen content in the HACNFs. The interpretation of the FTIR spectra sometimes encountered some difficulties in the identification of nitrogen functional groups, but the XPS could take over to perform this work. The activated samples carbonized at $900{ }^{\circ} \mathrm{C}$ featured the highest bulk nitrogen content (6.8 wt.\%) and surface nitrogen groups (5.4 at.\%). HACNFs are microporous adsorbents. The increase in the carbonization temperature $\left(>900{ }^{\circ} \mathrm{C}\right)$ or $\mathrm{CO}_{2}$ activation was capable of increasing the specific surface areas or pore volumes; however, the effect of the pore enlargement induced from the above stages would weaken the microporosity. $\mathrm{CO}_{2}$ adsorption on HACNFs was an exothermic reaction, and belonged to the physical adsorption. The $\mathrm{CO}_{2}$ adsorption performance on the HACNFs and their cyclic regeneration tests demonstrated that the HACNFs should be promising candidates as gas adsorbents.

Author Contributions: Conceptualization, Y.-C.C.; methodology, Y.-C.C.; software, W.-T.C.; validation, Y.-C.C.; investigation, C.-C.H.; data curation, W.-T.C. and C.-C.H.; writing-original draft preparation, Y.-C.C.; writing-review and editing, Y.-C.C.; visualization, Y.-C.C.; supervision, Y.-C.C.; project administration, Y.-C.C.; funding acquisition, Y.-C.C. All authors have read and agreed to the published version of the manuscript.

Funding: This research was funded by the Ministry of Science and Technology, Taiwan, grant numbers MOST 107-2221-E-155-002-.

Institutional Review Board Statement: Not applicable.

Informed Consent Statement: Not applicable.

Data Availability Statement: The data presented in this study are available on request from the corresponding author. The data are not publicly available due to privacy restrictions.

Acknowledgments: The authors would like to thank the Instrumentation Center at NTU for performing the FESEM and EA analyses, the Department of Chemical Engineering at NTU for performing the $\mathrm{N}_{2}$ adsorption-desorption analysis, the Instrumentation Center at NTHU for performing the XPS analysis, and the Department of Chemical Engineering and Materials Science at YZU for performing the FTIR analysis.

Conflicts of Interest: The authors declare no conflict of interest.

\section{References}

1. Khandaker, T.; Hossain, M.S.; Dhar, P.K.; Rahman, M.S.; Hossain, M.A.; Ahmed, M.B. Efficacies of carbon-based adsorbents for carbon dioxide capture. Processes 2020, 8, 654. [CrossRef]

2. Sharma, H.; Dhir, A. Capture of carbon dioxide using solid carbonaceous and non-carbonaceous adsorbents: A review. Environ. Chem. Lett. 2021, 19, 851-873. [CrossRef] 
3. Sharma, A.; Jindal, J.; Mittal, A.; Kumari, K.; Maken, S.; Kumar, N. Carbon materials as $\mathrm{CO}_{2}$ adsorbents: A review. Environ. Chem. Lett. 2021, 19, 875-910. [CrossRef]

4. de Souza, K.C.; Wickramaratne, N.P.; Ello, A.S.; Costa, M.J.F.; da Costa, C.E.F.; Jaroniec, M. Enhancement of $\mathrm{CO}_{2}$ adsorption on phenolic resin-based mesoporous carbons by $\mathrm{KOH}$ activation. Carbon 2013, 65, 334-340. [CrossRef]

5. Wickramaratne, N.P.; Jaroniec, M. Importance of small micropores in $\mathrm{CO}_{2}$ capture by phenolic resin-based activated carbon spheres. J. Mater. Chem. A 2013, 1, 112-116. [CrossRef]

6. Presser, V.; McDonough, J.; Yeon, S.H.; Gogotsi, Y. Effect of pore size on carbon dioxide sorption by carbide derived carbon. Energ. Environ. Sci. 2011, 4, 3059-3066. [CrossRef]

7. Pevida, C.; Drage, T.C.; Snape, C.E. Silica-templated melamine-formaldehyde resin derived adsorbents for $\mathrm{CO}_{2}$ capture. Carbon 2008, 46, 1464-1474. [CrossRef]

8. Maroto-Valer, M.M.; Tang, Z.; Zhang, Y. $\mathrm{CO}_{2}$ capture by activated and impregnated anthracites. Fuel Process. Technol. 2005, 86, 1487-1502. [CrossRef]

9. Ondarçuhu, T.; Joachim, C. Drawing a single nanofiber over hundreds of microns. Eur. Phys. Lett. 1998, 42, 215-220. [CrossRef]

10. Huang, Z.M.; Zhang, Y.Z.; Kotaki, M.; Ramakrishna, S. A review on polymer nanofibers by electrospinning and their applications in nanocomposites. Compos. Sci. Technol. 2003, 63, 2223-2253. [CrossRef]

11. Nasouri, K.; Shoushtari, A.M.; Kaflou, A. Investigation of polyacrylonitrile electrospun nanofibres morphology as a function of polymer concentration, viscosity and Berry number. Micro Nano Lett. 2012, 7, 423-426. [CrossRef]

12. Xing, X.; Wang, Y.; Li, B. Nanofiber drawing and nanodevice assembly in poly(trimethylene terephthalate). Opt. Express 2008, 16, 10815-10822. [CrossRef]

13. Yang, X.; Liu, Y.; Li, J.; Zhang, X. Influence of thermal decomposition on morphologies and magnetic properties of iron nanofibres via electrospinning. Micro Nano Lett. 2011, 6, 967-970. [CrossRef]

14. Feng, L.; Li, S.H.; Li, H.J.; Zhai, J.; Song, Y.; Jiang, L.; Zhu, D. Super hydrophobic surface of aligned polyacrylonitrile nanoflbers. Angew. Chem. Int. Ed. 2002, 41, 1221-1223. [CrossRef]

15. Martín, J.; Maiz, J.; Sacristan, J.; Mijangos, C. Tailored polymer-based nanorods and nanotubes by "template synthesis": From preparation to applications. Polymer 2012, 53, 1149-1166. [CrossRef]

16. Ma, P.X.; Zhang, R. Synthetic nano-scale fibrous extracellular matrix. J. Biomed. Mater. Res. 1999, 46, 60-72. [CrossRef]

17. Liu, G.; Ding, J.; Qiao, L.; Guo, A.; Dymov, B.P.; Gleeson, J.T.; Hashimoto, T.; Saijo, K. Polystyrene-block-poly(2cinnamoylethyl methacrylate) nanofibers preparation, characterization, and liquid crystalline properties. Chem. Eur. J. 1999, 5, 2740-2749. [CrossRef]

18. Wang, J.; Ouyang, Z.; Ren, Z.; Li, J.; Zhang, P.; Wei, G.; Su, Z. Self-assembled peptide nanofibers on graphene oxide as a novel nanohybrid for biomimetic mineralization of hydroxyapatite. Carbon 2015, 89, 20-30. [CrossRef]

19. Doshi, J.; Reneker, D.H. Electrospinning process and applications of electrospun fibers. J. Electrostat. 1995, 35, 151-160. [CrossRef]

20. Zhang, L.; Aboagye, A.; Kelkar, A.; Lai, C.; Fong, H. A review: Carbon nanofibers from electrospun polyacrylonitrile and their applications. J. Mater. Sci. 2014, 49, 463-480. [CrossRef]

21. Greiner, A.; Wendorff, J.H. Electrospinning: A fascinating method for the preparation of ultrathin fibers. Angew. Chem. Int. Ed. 2007, 46, 5670-5703. [CrossRef]

22. Ognibene, G.; Gangemi, C.M.A.; Spitaleri, L.; Gulino, A.; Purrello, R.; Cicala, G.; Fragalà, M.E. Role of the surface composition of the polyethersulfone-TiiP- $\mathrm{H}_{2} \mathrm{~T}_{4}$ fibers on lead removal: From electrostatic to coordinative binding. J. Mater. Sci. 2019, 54, 8023-8033. [CrossRef]

23. Gangemi, C.M.A.; Iudici, M.; Spitaleri, L.; Randazzo, R.; Gaeta, M.; D’Urso, A.; Gulino, A.; Purrello, R.; Fragalà, M.E. Polyethersulfone mats functionalized with porphyrin for removal of para-nitroaniline from aqueous solution. Molecules 2019, 24,3344 . [CrossRef] [PubMed]

24. Niu, H.; Lin, T. Fiber generators in needleless electrospinning. J. Nanomater. 2012, 725950. [CrossRef]

25. Reneker, D.H.; Yarin, A.L. Electrospinning jets and polymer nanofibers. Polymer 2008, 49, 2387-2425. [CrossRef]

26. Ahmadian, A.; Shafiee, A.; Aliahmad, N.; Agarwal, M. Overview of nano-fiber mats fabrication via electrospinning and morphology analysis. Textiles 2021, 1, 206-226. [CrossRef]

27. Li, D.; Xia, Y. Electrospinning of nanofibers: Reinventing the wheel? Adv. Mater. 2004, 16, 1151-1170. [CrossRef]

28. Koski, A.; Yim, K.; Shivkumar, S. Effect of molecular weight on fibrous PVA produced by electrospinning. Mater. Lett. 2004, 58, 493-497. [CrossRef]

29. Gupta, P.; Elkins, C.; Long, T.E.; Wilkes, G.L. Electrospinning of linear homopolymers of poly(methyl methacrylate): Exploring relationships between fiber formation, viscosity, molecular weight and concentration in a good solvent. Polymer 2005, 46, 4799-4810. [CrossRef]

30. Shenoy, S.L.; Bates, W.D.; Frisch, H.L.; Wnek, G.E. Role of chain entanglements on fiber formation during electrospinning of polymer solutions: Good solvent, non-specific polymer-polymer interaction limit. Polymer 2005, 46, 3372-3384. [CrossRef]

31. Hsu, C.M.; Shivkumar, S. Nano-sized beads and porous fiber constructs of poly(1'-caprolactone) produced by electrospinning. J. Mater. Sci. 2004, 39, 3003-3013. [CrossRef]

32. Sun, Z.; Zussman, E.; Yarin, A.L.; Wendorff, J.H.; Greiner, A. Compound core-shell polymer nanofibers by co-electrospinning. Adv. Mater. 2003, 15, 1929-1932. [CrossRef] 
33. Lin, T.; Wang, H.; Wang, X. Self-crimping bicomponent nanofibers electrospun from polyacrylonitrile and elastomeric polyurethane. Adv. Mater. 2005, 17, 2699-2703. [CrossRef]

34. Gbewonyo, S.; Carpenter, A.W.; Gause, C.B.; Mucha, N.R.; Zhang, L. Low thermal conductivity carbon fibrous composite nanomaterial enabled by multi-scale porous structure. Mater. Des. 2017, 134, 218-225. [CrossRef]

35. Zussman, E.; Yarin, A.L.; Bazilevsky, A.V.; Avrahami, R.; Feldman, M. Electrospun polyacrylonitrile/poly(methyl methacrylate)derived turbostratic carbon micro-/nanotubes. Adv. Mater. 2006, 18, 348-353. [CrossRef]

36. Xie, W.; Khan, S.; Rojas, O.J.; Parsons, G.N. Control of micro- and mesopores in carbon nanofibers and hollow carbon nanofibers derived from cellulose diacetate via vapor phase infiltration of diethyl zinc. ACS Sustain. Chem. Eng. 2018, 6, 13844-13853. [CrossRef]

37. Zhang, L.; Hsieh, Y.L. Carbon nanofibers with nanoporosity and hollow channels from binary polyacrylonitrile systems. Eur. Polym. J. 2009, 45, 47-56. [CrossRef]

38. Kaerkitcha, N.; Chuangchote, S.; Sagawa, T. Control of physical properties of carbon nanofibers obtained from coaxial electrospinning of PMMA and PAN with adjustable inner/outer nozzle-ends. Nanoscale Res. Lett. 2016, 11, 186. [CrossRef]

39. Sill, T.J.; von Recum, H.A. Electrospinning: Applications in drug delivery and tissue engineering. Biomaterials 2008, 29, 1989-2006. [CrossRef] [PubMed]

40. Qu, H.; Wei, S.; Guo, Z. Coaxial electrospun nanostructures and their applications. J. Mater. Chem. A 2013, 1, 11513-11528. [CrossRef]

41. El-Deen, A.G.; Barakat, N.A.M.; Khalild, K.A.; Kim, H.Y. Hollow carbon nanofibers as an effective electrode for brackish water desalination using the capacitive deionization process. New J. Chem. 2014, 38, 198-205. [CrossRef]

42. Park, S.H.; Jung, H.R.; Lee, W.J. Hollow activated carbon nanofibers prepared by electrospinning as counter electrodes for dye-sensitized solar cells. Electrochim. Acta 2013, 102, 423-428. [CrossRef]

43. Wu, Y.; Gao, M.; Li, X.; Liu, Y.; Pan, H. Preparation of mesohollow and microporous carbon nanofiber and its application in cathode material for lithium-sulfur batteries. J. Alloys Compd. 2014, 608, 220-228. [CrossRef]

44. Peng, Y.T.; Lo, C.T. Electrospun porous carbon nanofibers as lithium ion battery anodes. J. Solid State Electrochem. 2015, 19, 3401-3410. [CrossRef]

45. Li, L.; Peng, S.; Lee, J.K.Y.; Ji, D.; Srinivasan, M.; Ramakrishna, S. Electrospun hollow nanofibers for advanced secondary batteries. Nano Energy 2017, 39, 111-139. [CrossRef]

46. Zhang, T.; Qu, H.; Sun, K. Development of polydopamine coated electrospun PAN/PMMA nanofibrous membrane as composite separator for Lithium-ion batteries. Mater. Lett. 2019, 245, 10-13. [CrossRef]

47. Liu, Q.; Zhu, J.; Zhang, L.; Qiu, Y. Recent advances in energy materials by electrospinning. Renew. Sustain. Energy Rev. 2018, 81, 1825-1858. [CrossRef]

48. Zhao, W.; Yamamoto, Y.; Tagawa, S. Regulation of the thermal reactions of polyacrylonitrile by c-irradiation. Chem. Mater. 1999, 11, 1030-1034. [CrossRef]

49. Qin, X.H. Structure and property of electrospinning PAN nanofibers by different preoxidation temperature. J. Therm. Anal. Calorim. 2010, 99, 571-575. [CrossRef]

50. Othman, F.E.C.; Yusof, N.; Samitsu, S.; Abdullah, N.; Hamid, M.F.; Nagai, K.; Abidin, M.N.Z.; Azali, M.A.; Ismail, A.F.; Jaafar, J.; et al. Activated carbon nanofibers incorporated metal oxides for $\mathrm{CO}_{2}$ adsorption: Effects of different type of metal oxides. J. CO2 Util. 2021, 45, 101434. [CrossRef]

51. Ji, M.; Wang, C.; Bai, Y.; Yu, M.; Wang, Y. Structural evolution of polyacrylonitrile precursor fibers during preoxidation and carbonization. Polym. Bull. 2007, 59, 527-536. [CrossRef]

52. Suzuki, M. Adsorption Engineering; Elsevier Science: Amsterdam, The Netherlands, 1990.

53. Lee, J.S.; Kim, J.H.; Kim, J.T.; Suh, J.K.; Lee, J.M.; Lee, C.H. Adsorption equilibria of $\mathrm{CO}_{2}$ on zeolite $13 \mathrm{X}$ and zeolite X/activated carbon composite. J. Chem. Eng. Data 2002, 47, 1237-1242. [CrossRef]

54. Lee, B.S.; Park, K.M.; Yu, W.R.; Youk, J.H. An effective method for manufacturing hollow carbon nanofibers and microstructural analysis. Macromol. Res. 2012, 20, 605-613. [CrossRef]

55. Peterson, J.D.; Vyazovkin, S.; Wight, C.A. Kinetic study of stabilizing effect of oxygen on thermal degradation of poly(methyl methacrylate). J. Phys. Chem. B 1999, 103, 8087. [CrossRef]

56. Wangxi, Z.; Jie, L.; Gang, W. Evolution of structure and properties of PAN precursors during their conversion to carbon fibers. Carbon 2003, 41, 2805-2812. [CrossRef]

57. Yoon, C.M.; Long, D.; Jang, S.M.; Qiao, W.; Ling, L.; Miyawaki, J.; Rhee, C.K.; Mochida, I.; Yoon, S.H. Electrochemical surface oxidation of carbon nanofibers. Carbon 2011, 49, 96-105. [CrossRef]

58. Wickramaarachchi, K.; Sundaram, M.M.; Henry, D.J.; Gao, X. Alginate biopolymer effect on the electrodeposition of manganese dioxide on electrodes for supercapacitors. ACS Appl. Energy Mater. 2021, 4, 7040-7051. [CrossRef]

59. Ismagilov, Z.R.; Shalagina, A.E.; Podyacheva, O.Y.; Ischenko, A.V.; Kibis, L.S.; Boronin, A.I.; Chesalov, Y.A.; Kochubey, D.I.; Romanenko, A.I.; Anikeeva, O.B.; et al. Structure and electrical conductivity of nitrogen-doped carbon nanofibers. Carbon 2009, 47, 1922-1929. [CrossRef]

60. Sundaram, M.M.; Appadoo, D. Traditional salt-in-water electrolyte vs. water-in-salt electrolyte with binary metal oxide for symmetric supercapacitors: Capacitive vs. faradaic. Dalton Trans. 2020, 49, 11743-11755. [CrossRef] 
61. Tuccitto, N.; Riela, L.; Zammataro, A.; Spitaleri, L.; Li-Destri, G.; Sfuncia, G.; Nicotra, G.; Pappalardo, A.; Capizzi, G.; Sfrazzetto, G.T. Functionalized carbon nanoparticle-based sensors for chemical warfare agents. ACS Appl. Nano Mater. 2020, 3, 8182-8191. [CrossRef]

62. Giofrè, S.V.; Tiecco, M.; Celesti, C.; Patanè, S.; Triolo, C.; Gulino, A.; Spitaleri, L.; Scalese, S.; Scuderi, M.; Iannazzo, D. Ecofriendly 1,3-dipolar cycloaddition reactions on graphene quantum dots in natural deep eutectic solvent. Nanomaterials 2020, 10, 2549. [CrossRef]

63. Graf, N.; Yegen, E.; Gross, T.; Lippitz, A.; Weigel, W.; Krakert, S.; Terfort, A.; Unger, W.E.S. XPS and NEXAFS studies of aliphatic and aromatic amine species on functionalized surfaces. Surf. Sci. 2009, 603, 2849-2860. [CrossRef]

64. Pamula, E.; Rouxhet, P.G. Bulk and surface chemical functionalities of Type III PAN-based carbon fibers. Carbon 2003, 41, 1905-1915. [CrossRef]

65. Gulino, A. Structural and electronic characterization of self-assembled molecular nanoarchitectures by X-ray photoelectron spectroscopy. Anal. Bioanal. Chem. 2013, 405, 1479-1495. [CrossRef] [PubMed]

66. Contino, A.; Maccarrone, G.; Fragalà, M.E.; Spitaleri, L.; Gulino, A. Conjugated gold-porphyrin monolayers assembled on inorganic surfaces. Chem. Eur. J. 2017, 23, 14937-14943. [CrossRef] [PubMed]

67. Sharma, P.; Minakshi, M.; Whale, J.; Jean-Fulcrand, A.; Garnweitner, G. Effect of the anionic counterpart: Molybdate vs. tungstate in energy storage for pseudo-capacitor applications. Nanomaterials 2021, 11, 580. [CrossRef] [PubMed]

68. Sevilla, M.; Falco, C.; Titirici, M.M.; Fuertes, A.B. High-performance $\mathrm{CO}_{2}$ sorbents from algae. RSC Adv. 2012, 2, 12792-12797. [CrossRef]

69. Fan, X.; Zhang, L.; Zhang, G.; Shu, Z.; Shi, J. Chitosan derived nitrogen-doped microporous carbons for high performance $\mathrm{CO}_{2}$ capture. Carbon 2013, 61, 423-430. [CrossRef]

70. Hao, G.P.; Li, W.C.; Qian, D.; Lu, A.H. Rapid synthesis of nitrogen-doped porous carbon monolith for $\mathrm{CO}_{2}$ capture. Adv. Mater 2010, 22, 853-857. [CrossRef]

71. Toth, J. Isotherm equations for monolayer adsorption of gases on heterogeneous solid surfaces. In Fundamentals of Adsorption; Myers, A., Belfort, G., Eds.; Engineering Foundation: New York, NY, USA, 1984; pp. 657-665.

72. To, J.W.F.; He, J.; Mei, J.; Haghpanah, R.; Chen, Z.; Kurosawa, T. Hierarchical N-doped carbon as $\mathrm{CO}_{2}$ adsorbent with high $\mathrm{CO}_{2}$ selectivity from rationally designed polypyrrole precursor. J. Am. Chem. Soc. 2016, 38, 1001-1009. [CrossRef]

73. Chiang, Y.C.; Huang, C.C.; Chin, W.T. Carbon dioxide adsorption on carbon nanofibers with different porous structures. Appl. Sci. 2021, 11, 7724. [CrossRef]

74. Chiang, Y.C.; Lee, S.T.; Leo, Y.J.; Tseng, T.L. Importance of pore structure and surface chemistry in carbon dioxide adsorption on electrospun carbon nanofiber. Sens. Mater. 2020, 32, 2277-2288. [CrossRef]

75. Chiang, Y.C.; Wu, C.Y.; Chen, Y.J. Effects of activation on the properties of electrospun carbon nanofibers and their adsorption performance for carbon dioxide. Sep. Purif. Technol. 2020, 233, 116040. [CrossRef]

76. Xiong, L.; Wang, X.F.; Li, L.; Jin, L.; Zhang, Y.G.; Song, S.L.; Liu, R.P. Nitrogen-enriched porous carbon fiber as $\mathrm{CO}_{2}$ adsorbent with superior $\mathrm{CO}_{2}$ selectivity by air activation. Energy Fuels 2019, 33, 12558-12567. [CrossRef]

77. Heo, Y.J.; Zhang, Y.; Rhee, K.Y.; Park, S.J. Synthesis of PAN/PVDF nanofiber composites-based carbon adsorbents for $\mathrm{CO}_{2}$ capture. Compos. B 2019, 156, 95-99. [CrossRef]

78. Jeong, D.; Jie, W.; Adelodun, A.A.; Kim, S.; Jo, Y. Electrospun melamine-blended activated carbon nanofibers for enhanced control of indoor $\mathrm{CO}_{2}$. J. Appl. Polym. Sci. 2019, 136, 47747. [CrossRef] 